Received: 5 September 2016

Accepted: 21 September 2017

Published online: 13 October 2017

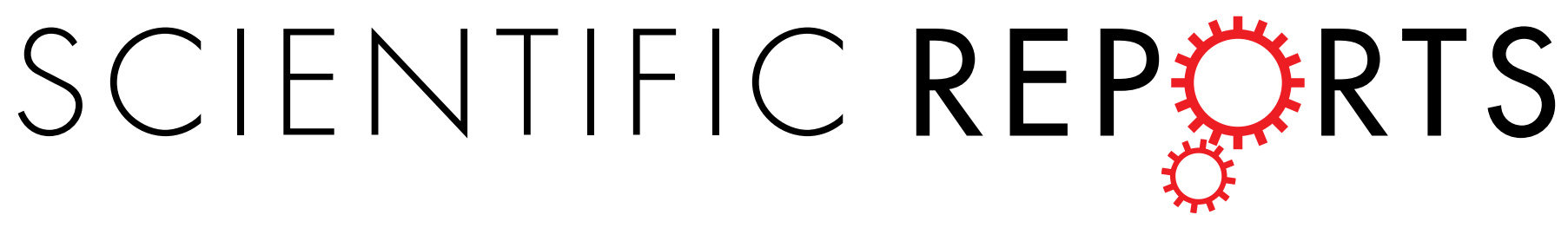

\title{
OPEN \\ Astrocyte calcium waves propagate proximally by gap junction and distally by extracellular diffusion of ATP released from volume- regulated anion channels
}

\begin{abstract}
Yuki Fujii, Shohei Maekawa \& Mitsuhiro Morita
Wave-like propagation of $\left[\mathrm{Ca}^{2+}\right]_{i}$ increases is a remarkable intercellular communication characteristic in astrocyte networks, intercalating neural circuits and vasculature. Mechanically-induced $\left[\mathrm{Ca}^{2+}\right]_{i}$ increases and their subsequent propagation to neighboring astrocytes in culture is a classical model of astrocyte calcium wave and is known to be mediated by gap junction and extracellular ATP, but the role of each pathway remains unclear. Pharmacologic analysis of time-dependent distribution of $\left[\mathrm{Ca}^{2+}\right]_{i}$ revealed three distinct $\left[\mathrm{Ca}^{2+}\right]_{\mathrm{i}}$ increases, the largest being in stimulated cells independent of extracellular $\mathrm{Ca}^{2+}$ and inositol 1,4,5-trisphosphate-induced $\mathrm{Ca}^{2+}$ release. In addition, persistent $\left[\mathrm{Ca}^{2+}\right]_{\mathrm{i}}$ increases were found to propagate rapidly via gap junctions in the proximal region, and transient $\left[\mathrm{Ca}^{2+}\right]_{i}$ increases were found to propagate slowly via extracellular ATP in the distal region. Simultaneous imaging of astrocyte $\left[\mathrm{Ca}^{2+}\right]_{i}$ and extracellular ATP, the latter of which was measured by an ATP sniffing cell, revealed that ATP was released within the proximal region by volume-regulated anion channel in a $\left[\mathrm{Ca}^{2+}\right]_{\mathrm{i}}$ independent manner. This detailed analysis of a classical model is the first to address the different contributions of two major pathways of calcium waves, gap junctions and extracellular ATP.
\end{abstract}

Deeper understanding of the mechanisms underlying the spatio-temporal diversity and complexity of $\left[\mathrm{Ca}^{2+}\right]_{\mathrm{i}}$ increases in astrocytes is crucial for exploring the physiological and pathological functions of this glial cell population. Calcium waves are a remarkable aspect of $\left[\mathrm{Ca}^{2+}\right]_{\mathrm{i}}$ dynamics in astrocytes, and a unique type of intercellular communication in astrocyte networks, intercalating neuronal circuitries and vasculature. Various pharmacologic and physical stimuli have been found to induce $\left[\mathrm{Ca}^{2+}\right]_{\mathrm{i}}$ increases propagating between astrocytes in cell cultures $^{1,2}$, in brain slices ${ }^{3,4}$, and in other in vivo preparations ${ }^{5,6}$. These calcium waves are regarded as transmitting physiologic and pathologic signals within the brain, because they influence the activities of adjacent neurons $\mathrm{s}^{7,8}$, microglia ${ }^{9}$, and endothelial cells ${ }^{10}$. Furthermore, recent studies have demonstrated the involvement of astrocyte networks and calcium waves in regulating neuronal activities ${ }^{11}$ and neurological diseases ${ }^{12,13}$.

Because calcium waves can propagate between astrocytes in the absence of physical contact ${ }^{14}$, they are likely induced by intracellular and extracellular signals in a synergistic manner. Astrocytes are intracellularly connected via connexin channels ${ }^{15}$, and their transmission of $\mathrm{Ca}^{2+}$ and $\mathrm{IP}_{3}$ via gap junctions has been demonstrated experimentally and theoretically ${ }^{16,17}$. Moreover, astrocytes are equipped with ATP release mechanisms and ATP receptors inducing $\left[\mathrm{Ca}^{2+}\right]_{\mathrm{i}}$ increases ${ }^{18}$, and purinergic signaling has been found to be involved in calcium waves ${ }^{19,20}$. Furthermore, gap junction and purinergic signaling are regulated in a supplementary manner to maintain calcium waves ${ }^{21}$. However, the contributions of these components to the dynamics and functions of calcium waves, and the mechanisms involved in initiating $\left[\mathrm{Ca}^{2+}\right]_{\mathrm{i}}$ increases and release ATP in calcium waves are incompletely understood.

Theoretical ${ }^{17}$ and experimental ${ }^{1,2}$ studies have shown that calcium waves can be mechanically induced by gently touching cultured astrocytes with tips of glass pipettes. The present analysis of this classical model pharmacologically and by using an ATP sniffing cell revealed distinct $\left[\mathrm{Ca}^{2+}\right]_{i}$ increases during calcium waves. This 

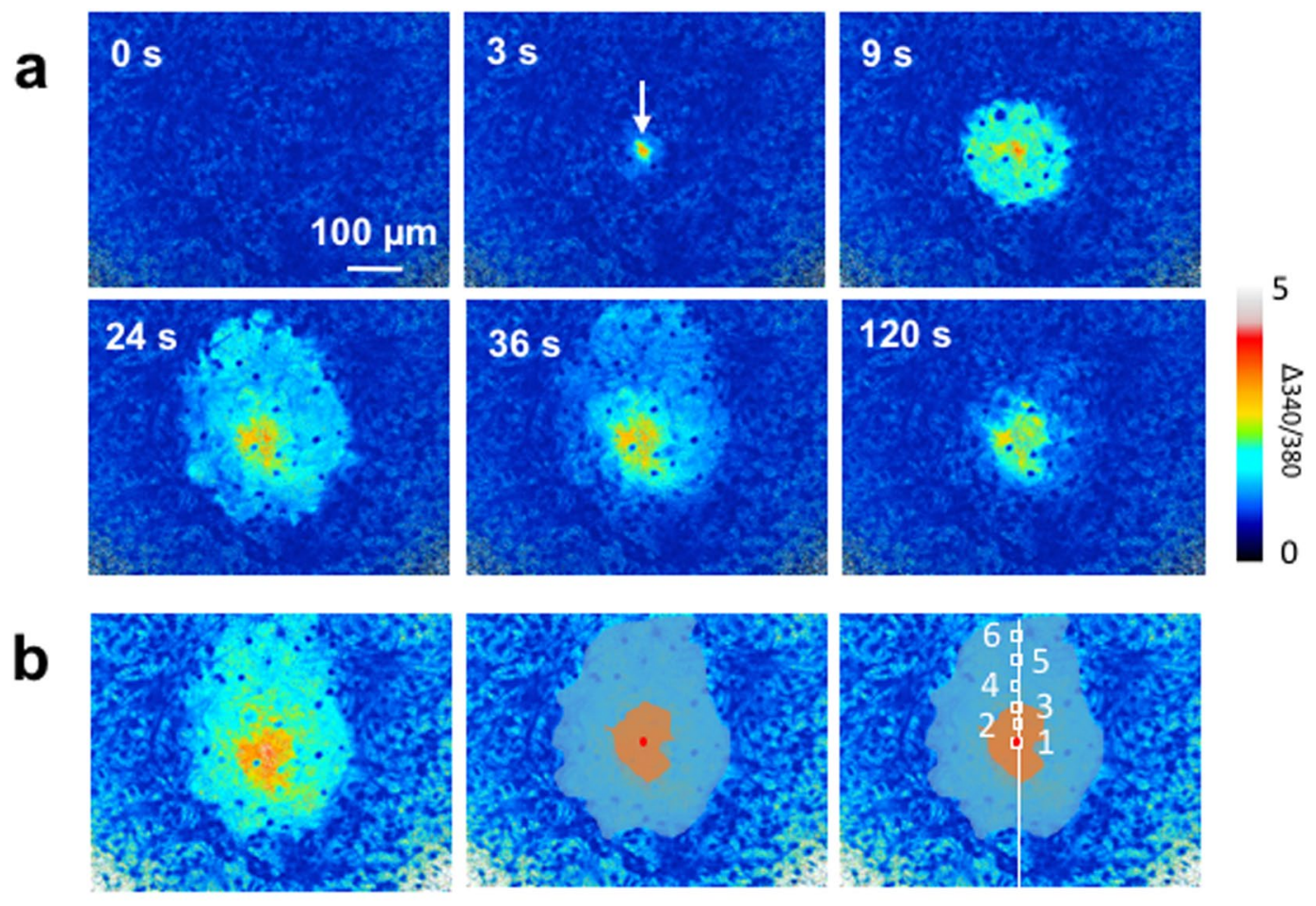

C

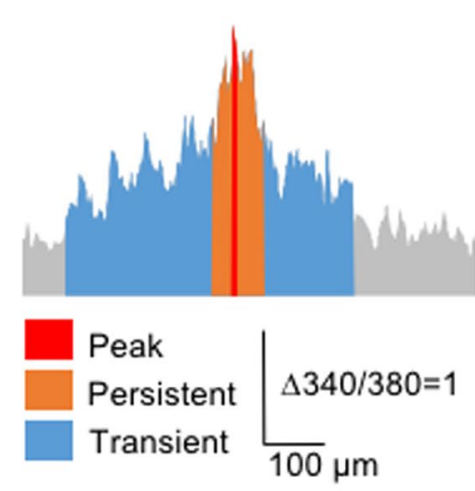

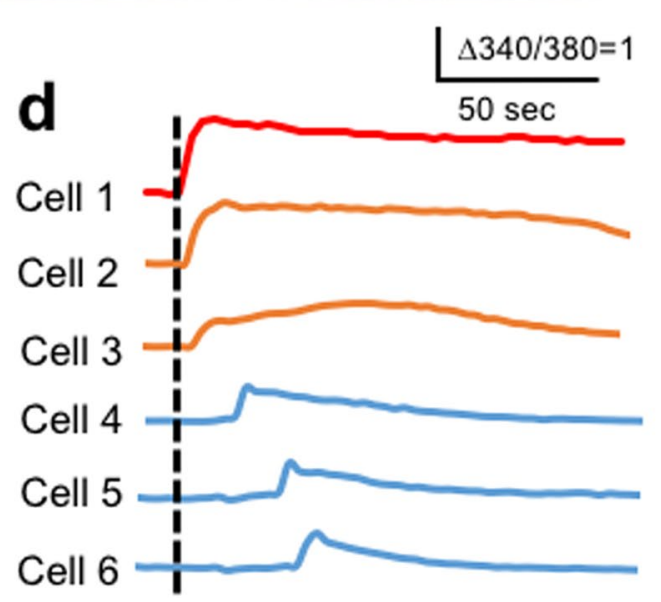

Figure 1. Distinct components of $\left[\mathrm{Ca}^{2+}\right]_{\mathrm{i}}$ increases in an astrocyte calcium wave. (a) Representative Fura2 ratio $(\Delta 340 / 380)$ images of an astrocyte calcium wave $0,3,9,24,36$ and $120 \mathrm{sec}$ after mechanical stimulation (arrow). (b) Distribution of $\left[\mathrm{Ca}^{2+}\right]_{\mathrm{i}}$ increases during the calcium wave. The maximum $\left[\mathrm{Ca}^{2+}\right]_{\mathrm{i}}$ projection, in which each pixel represents the maximum $\Delta 340 / 380$ during the calcium wave (left). The peak $\left[\mathrm{Ca}^{2+}\right]_{\mathrm{i}}$ increase (red), which is the $\left[\mathrm{Ca}^{2+}\right]_{\mathrm{i}}$ increase in the mechanically-stimulated cell, and the persistent (orange) and transient (blue) $\left[\mathrm{Ca}^{2+}\right]_{\mathrm{i}}$ increases, in which the $\Delta 340 / 380$ ratio of each pixel sustained above and declined below $30 \%$ of the mean $\Delta 340 / 380$ ratio of pixels within the peak $\left[\mathrm{Ca}^{2+}\right]_{\mathrm{i}}$ increase until $120 \mathrm{sec}$, respectively are shown overlaid on the maximum $\left[\mathrm{Ca}^{2+}\right]_{\mathrm{i}}$ projection (center). A Line and cells for the analyses in (c) and (d) are indicated in the right panel. (c) Histogram of the maximum $\Delta 340 / 380$ along the line in the right panel of (b). (d) Timedependent changes in $\left[\mathrm{Ca}^{2+}\right]_{\mathrm{i}}$ in cells $1-6$ in the right panel of $(\mathbf{b})$.

study was therefore designed to assess the distinct contributions of gap junction and extracellular ATP and the ATP release mechanism in calcium waves, revealing novel aspects of the diverse and complicated dynamics of astrocyte $\left[\mathrm{Ca}^{2+}\right]_{\mathrm{i}}$.

\section{Results}

Components of $\left[\mathrm{Ca}^{2+}\right]_{i}$ increases in calcium waves. Figure 1a shows a representative calcium wave induced by mechanical stimulation of cultured astrocytes. The $\left[\mathrm{Ca}^{2+}\right]_{\mathrm{i}}$ increase in the mechanically-stimulated cell (arrow) propagated to adjacent cells, and the area of $\left[\mathrm{Ca}^{2+}\right]_{\mathrm{i}}$ increases reached a maximum at $24 \mathrm{sec}$. Then, $\left[\mathrm{Ca}^{2+}\right]_{\mathrm{i}}$ in the distal region declined to the baseline by $120 \mathrm{sec}$, whereas that proximal to the stimulated cell remained elevated for longer than $120 \mathrm{sec}$. The distribution of $\left[\mathrm{Ca}^{2+}\right]_{\mathrm{i}}$ increases was expressed as a maximum $\left[\mathrm{Ca}^{2+}\right]_{\mathrm{i}}$ projection, in which each pixel represents the maximum $\Delta 340 / 380$ ratio during the calcium wave (Fig. $1 \mathrm{~b}$ 

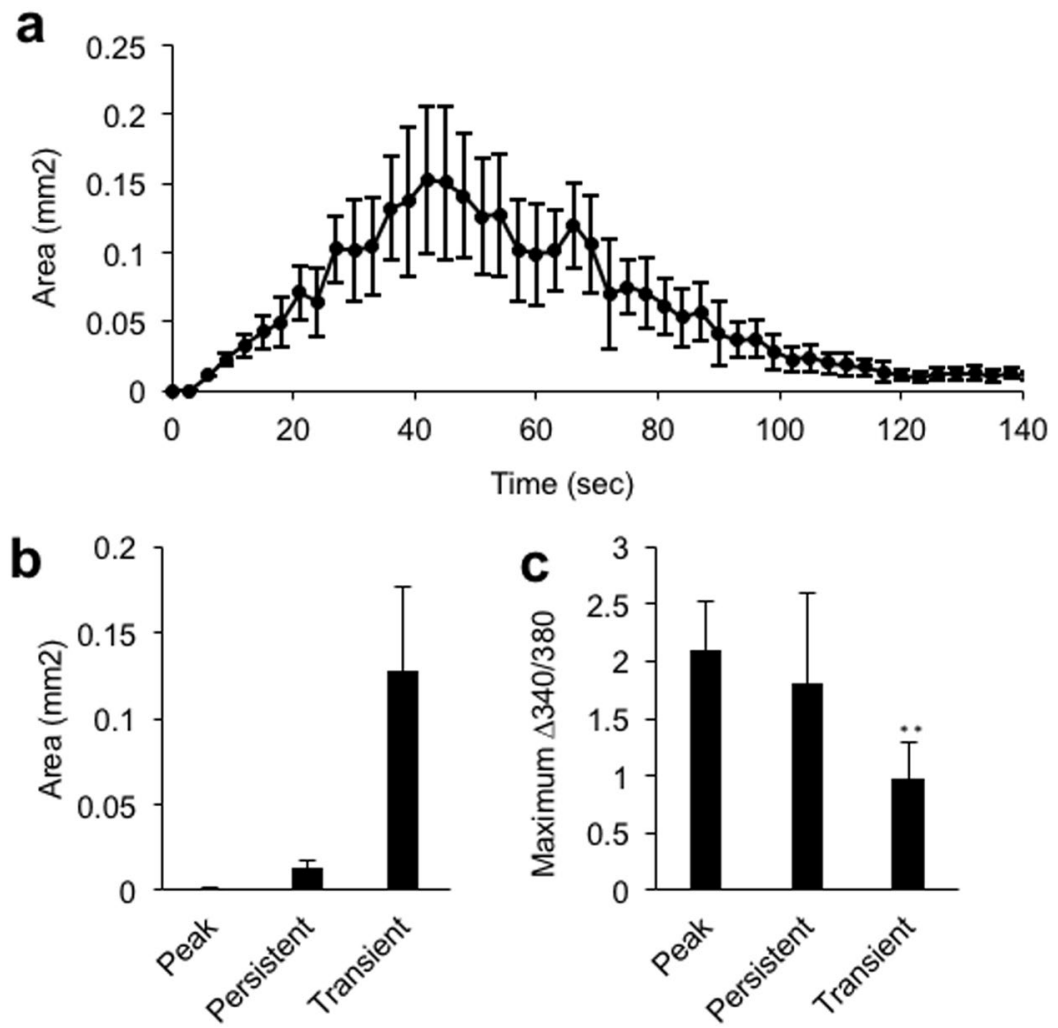

Figure 2. Time-dependent changes of area of $\left[\mathrm{Ca}^{2+}\right]_{\mathrm{i}}$ increase during calcium waves. Calcium waves $(\mathrm{n}=10$ experiments) were subjected to the following analysis. The area of $\left[\mathrm{Ca}^{2+}\right]_{\mathrm{i}}$ increase was calculated from the total number of pixels whose $\Delta 340 / 380$ ratio was above $30 \%$ of that of the peak $\left[\mathrm{Ca}^{2+}\right]_{\mathrm{i}}$ increase to distinguish the transient from the persistent increases, Fig. 1. (a) Averaged area of $\left[\mathrm{Ca}^{2+}\right]_{\mathrm{i}}$ increases at each time point. Maximum areas $(\mathbf{b})$ and maximum $\left[\mathrm{Ca}^{2+}\right]_{\mathrm{i}}$ increases $(\mathbf{c})$ of calcium wave components. $* * \mathrm{p}<0.01$ versus Peak, Tukey post hoc test after one-way ANOVA.

left). As shown in Fig. 1 b center, we defined the peak $\left[\mathrm{Ca}^{2+}\right]_{\mathrm{i}}$ increase (red) as $\left[\mathrm{Ca}^{2+}\right]_{\mathrm{i}}$ increase in the stimulated cell, and the persistent (orange) and transient (blue) $\left[\mathrm{Ca}^{2+}\right]_{\mathrm{i}}$ increases as $\left[\mathrm{Ca}^{2+}\right]_{\mathrm{i}}$ increases sustained and declined until $120 \mathrm{sec}$, respectively. The appropriateness of $120 \mathrm{sec}$ was clarified later. The histogram of maximum $\left[\mathrm{Ca}^{2+}\right]_{\mathrm{i}}$ increases along a line in Fig. $1 \mathrm{~b}$ right, shows that the peak $\left[\mathrm{Ca}^{2+}\right]_{\mathrm{i}}$ increase was the largest $\left[\mathrm{Ca}^{2+}\right]_{\mathrm{i}}$ increase during the calcium wave, and the persistent $\left[\mathrm{Ca}^{2+}\right]_{\mathrm{i}}$ increases were larger than the transient $\left[\mathrm{Ca}^{2+}\right]_{\mathrm{i}}$ increases (Fig. 1c). The $\left[\mathrm{Ca}^{2+}\right]_{\mathrm{i}}$ increases of individual cells in the region of the peak and persistent $\left[\mathrm{Ca}^{2+}\right]_{\mathrm{i}}$ increases $($ Cell $1-3)$ were persistent, whereas those in the region of transient $\left[\mathrm{Ca}^{2+}\right]_{\mathrm{i}}$ increases (Cell 4-6) were transient (Fig. 1d). These findings suggested that the peak, persistent and transient $\left[\mathrm{Ca}^{2+}\right]_{\mathrm{i}}$ increases were distinct components of the same calcium wave.

The time dependent changes of areas of $\left[\mathrm{Ca}^{2+}\right]_{\mathrm{i}}$ increases were further analyzed by averaging 10 calcium waves. The area of $\left[\mathrm{Ca}^{2+}\right]_{\mathrm{i}}$ increases peaked at $40 \mathrm{sec}$ and declined to become constant at $120 \mathrm{sec}$ as shown in Fig. 2a. Thus, it is appropriate to define the persistent $\left[\mathrm{Ca}^{2+}\right]_{\mathrm{i}}$ increase depending on the area of $\left[\mathrm{Ca}^{2+}\right]_{\mathrm{i}}$ increase at $120 \mathrm{sec}$. The areas of peak, persistent and transient $\left[\mathrm{Ca}^{2+}\right]_{\mathrm{i}}$ increases were $1133 \pm 453 \mu \mathrm{m}^{2}, 13069 \pm 4574 \mu \mathrm{m}^{2}$ and $127633 \pm 51000 \mu \mathrm{m}^{2}$, respectively (Fig. $2 \mathrm{~b}$ ), equivalent to circles with radii of $19 \mu \mathrm{m}, 65 \mu \mathrm{m}$ and $201 \mu \mathrm{m}$ respectively. The averaged maximum $\left[\mathrm{Ca}^{2+}\right]_{\mathrm{i}}$ in the areas of peak and persistent $\left[\mathrm{Ca}^{2+}\right]_{\mathrm{i}}$ increases did not significantly differ, but that in the area of transient $\left[\mathrm{Ca}^{2+}\right]_{\mathrm{i}}$ increases was significantly smaller than that in the area of peak $\left[\mathrm{Ca}^{2+}\right]_{\mathrm{i}}$ increases by $46 \%$ as shown in Fig. $2 \mathrm{c}$. These results further confirm the difference between transient and persistent $\left[\mathrm{Ca}^{2+}\right]_{\mathrm{i}}$ increases.

Mechanisms increasing $\left[\mathrm{Ca}^{2+}\right]_{\mathrm{i}}$ in calcium waves. The mechanisms underlying the $\left[\mathrm{Ca}^{2+}\right]_{\mathrm{i}}$ increases during calcium waves were pharmacologically examined by omitting extracellular $\mathrm{Ca}^{2+}\left(\mathrm{Ca}^{2+}\right.$-free), which inhibits $\mathrm{Ca}^{2+}$ influx; and by treating cells with $1 \mu \mathrm{M}$ thapsigargin (TG), $10 \mu \mathrm{M}$ U73122 and $20 \mu \mathrm{M}$ Xestospongin C (Xest $\mathrm{C}$ ), which inhibit, calcium storage, inositol1,4,5-trisphosphate $\left(\mathrm{IP}_{3}\right)$ production and $\mathrm{IP}_{3}$ receptor, respectively. Figure 3 a shows representative calcium waves of control $(-), \mathrm{Ca}^{2+}$-free and TG-treated cells. Omitting extracellular $\mathrm{Ca}^{2+}$ was found to eliminate the persistent $\left[\mathrm{Ca}^{2+}\right]_{\mathrm{i}}$ increases without affecting the peak $\left[\mathrm{Ca}^{2+}\right]_{\mathrm{i}}$ increase or propagation of the calcium wave, whereas treating with thapsigargin abolished the calcium wave without affecting the peak $\left[\mathrm{Ca}^{2+}\right]_{\mathrm{i}}$ increase. Figure $3 \mathrm{~b}$ shows quantitative analyses of the calcium wave components. Amplitudes of the peak $\left[\mathrm{Ca}^{2+}\right]_{\mathrm{i}}$ increases were not significantly affected by any pharmacologic treatment, indicating that the peak $\left[\mathrm{Ca}^{2+}\right]_{\mathrm{i}}$ increases were not mediated by $\mathrm{Ca}^{2+}$ influx or $\mathrm{IP}_{3}$-induced $\mathrm{Ca}^{2+}$ release (IICR), and that alterations of calcium waves described below did not reflect the difference of initial $\left[\mathrm{Ca}^{2+}\right]_{\mathrm{i}}$ increases before propagations. In 
a
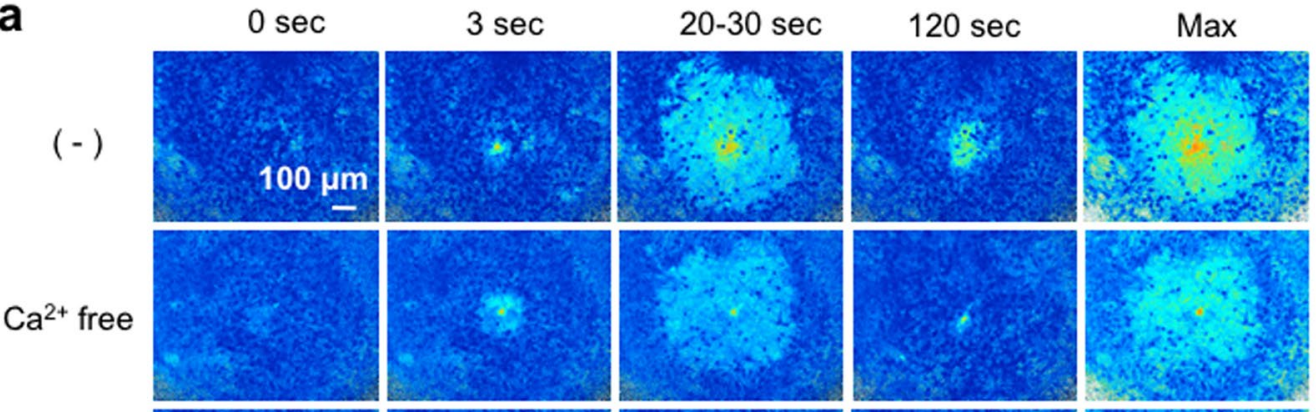

TG
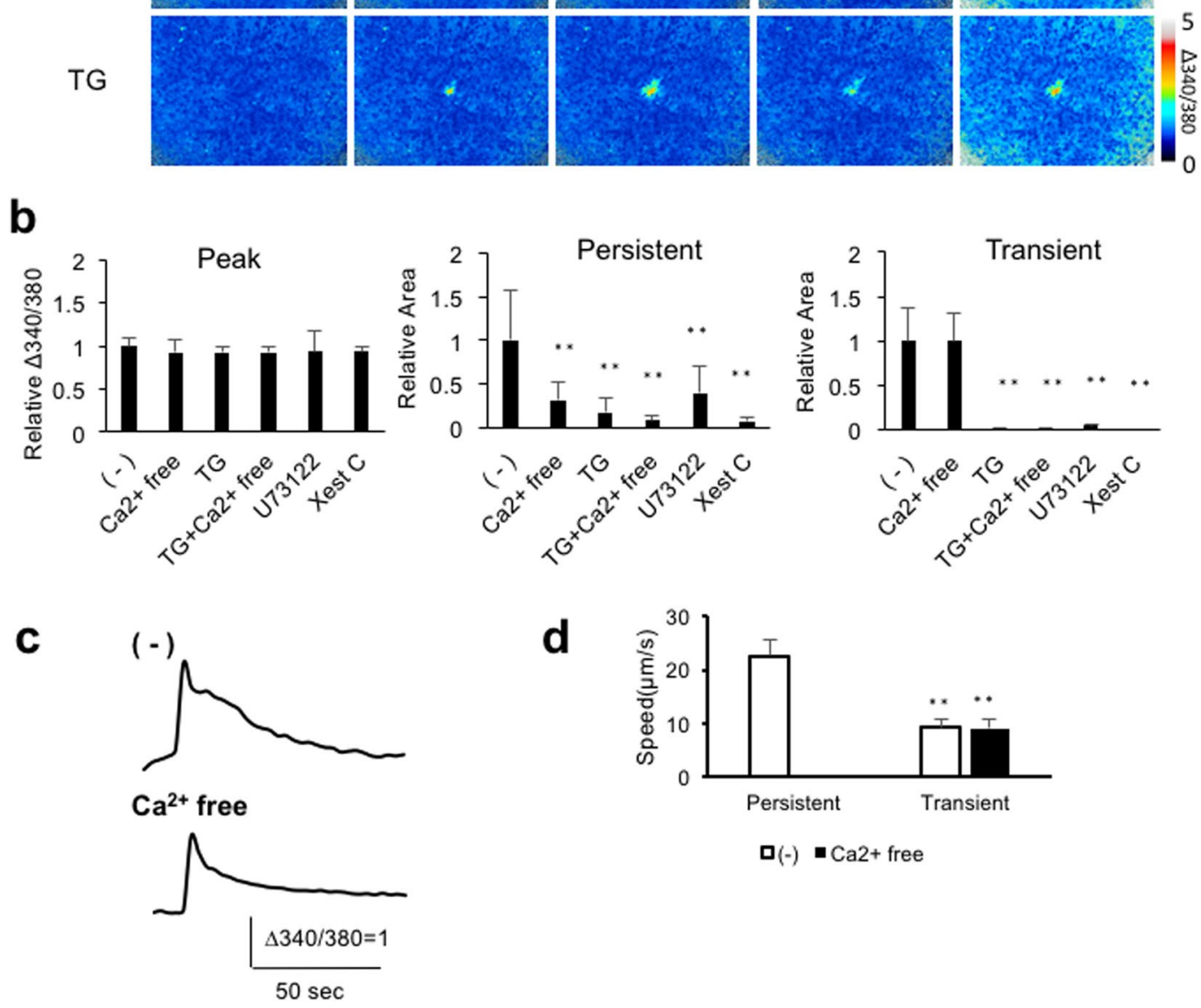

$\mathbf{Q}(-)=\mathrm{Ca} 2+$ free

Figure 3. Pharmacologic characterization of $\left[\mathrm{Ca}^{2+}\right]_{\mathrm{i}}$ increases during calcium waves. Astrocytes were treated with $\mathrm{Ca}^{2+}$-free extracellular solution ( $\mathrm{Ca}^{2+}$-free), $1 \mu \mathrm{M}$ thapsigargin (TG), $10 \mu \mathrm{M}$ U73122 or $20 \mu \mathrm{M}$ Xestospongin C (Xest C) for 10 min prior to mechanical stimulation. (a) Representative calcium waves of control (-), $\mathrm{Ca}^{2+}$-free and TG-treated cells. Baseline $\left[\mathrm{Ca}^{2+}\right]_{\mathrm{i}}(0 \mathrm{sec})$, initial $\left[\mathrm{Ca}^{2+}\right]_{\mathrm{i}}$ increase $(3 \mathrm{sec})$, maximallypropagated $\left[\mathrm{Ca}^{2+}\right]_{\mathrm{i}}$ increase $(20-30 \mathrm{sec})$, sustained $\left[\mathrm{Ca}^{2+}\right]_{\mathrm{i}}$ increase $(120 \mathrm{sec})$ and the maximum $\left[\mathrm{Ca}^{2+}\right]_{\mathrm{i}}$ projection (Max). (b) Amplitudes of the peak $\left[\mathrm{Ca}^{2+}\right]_{\mathrm{i}}$ increases (Peak $\Delta 340 / 380$, left), and areas of the persistent (center) and transient (right) $\left[\mathrm{Ca}^{2+}\right]_{\mathrm{i}}$ increases normalized to control. $\mathrm{n}=8$ experiments; $* * \mathrm{p}<0.01$ versus $(-)$, Bonferroni's multiple comparison test after one-way ANOVA. (c) Representative transient $\left[\mathrm{Ca}^{2+}\right]_{\mathrm{i}}$ increases in individual cells of control and $\mathrm{Ca}^{2+}$-free treated cultures. (d) Effects of extracellular $\mathrm{Ca}^{2+}$ on the velocities of calcium wave propagations in the regions of persistent or transient $\left[\mathrm{Ca}^{2+}\right]_{\mathrm{i}}$ increases. $\mathrm{n}=6$ experiments; $* * \mathrm{p}<0.01$ versus $(-)$ in the region of persistent $\left[\mathrm{Ca}^{2+}\right]_{\mathrm{i}}$ increases, $(-)$, Bonferroni's multiple comparison test after one-way ANOVA.

contrast, incubation of cells with $\mathrm{Ca}^{2+}$-free medium, TG, $\mathrm{TG}+\mathrm{Ca}^{2+}$-free medium, U73122, and Xest $\mathrm{C}$ resulted in significant reductions in areas of the persistent $\left[\mathrm{Ca}^{2+}\right]_{\mathrm{i}}$ increases to $32 \%, 18 \%, 9 \%, 40 \%$, and $8 \%$, respectively. The elimination of persistent $\left[\mathrm{Ca}^{2+}\right]_{\mathrm{i}}$ increases was partial in some experiments of $\mathrm{Ca}^{2+}$-free group, presumably due to insufficient reduction of extracellular $\mathrm{Ca}^{2+}$ concentration in the nominally $\mathrm{Ca}^{2+}$-free condition. Although $\mathrm{Ca}^{2+}$-free medium had no effect on areas of the transient $\left[\mathrm{Ca}^{2+}\right]_{\mathrm{i}}$ increases, the latter was significantly reduced by TG, TG $+\mathrm{Ca}^{2+}$-free, $\mathrm{U} 73122$ and Xest $\mathrm{C}$ to $2 \%, 2 \%, 5 \%$ and $1 \%$, respectively. These findings indicate that the persistent $\left[\mathrm{Ca}^{2+}\right]_{\mathrm{i}}$ increase is maintained synergistically by $\mathrm{Ca}^{2+}$ influx and IICR, whereas the transient $\left[\mathrm{Ca}^{2+}\right]_{\mathrm{i}}$ increases are mediated by IICR alone. 
a

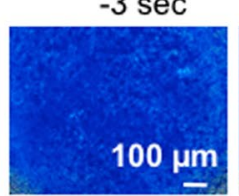

CBX

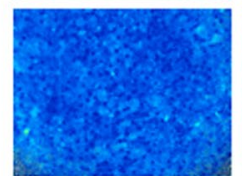

Suramin

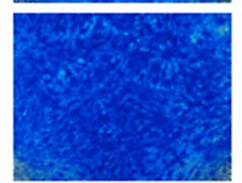

b
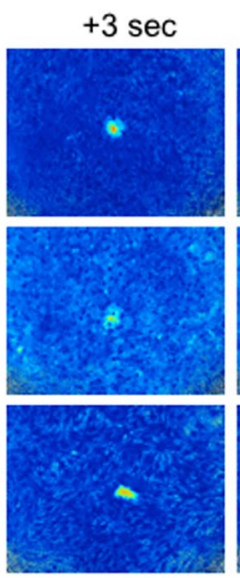
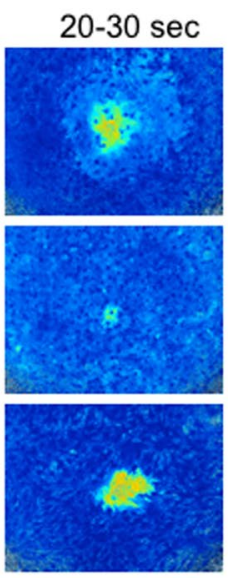

$120 \mathrm{sec}$
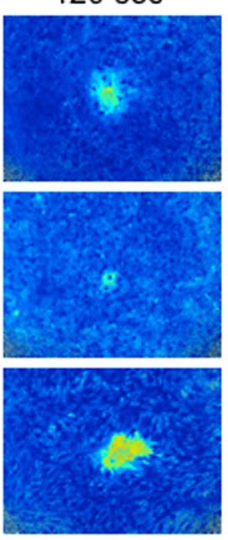
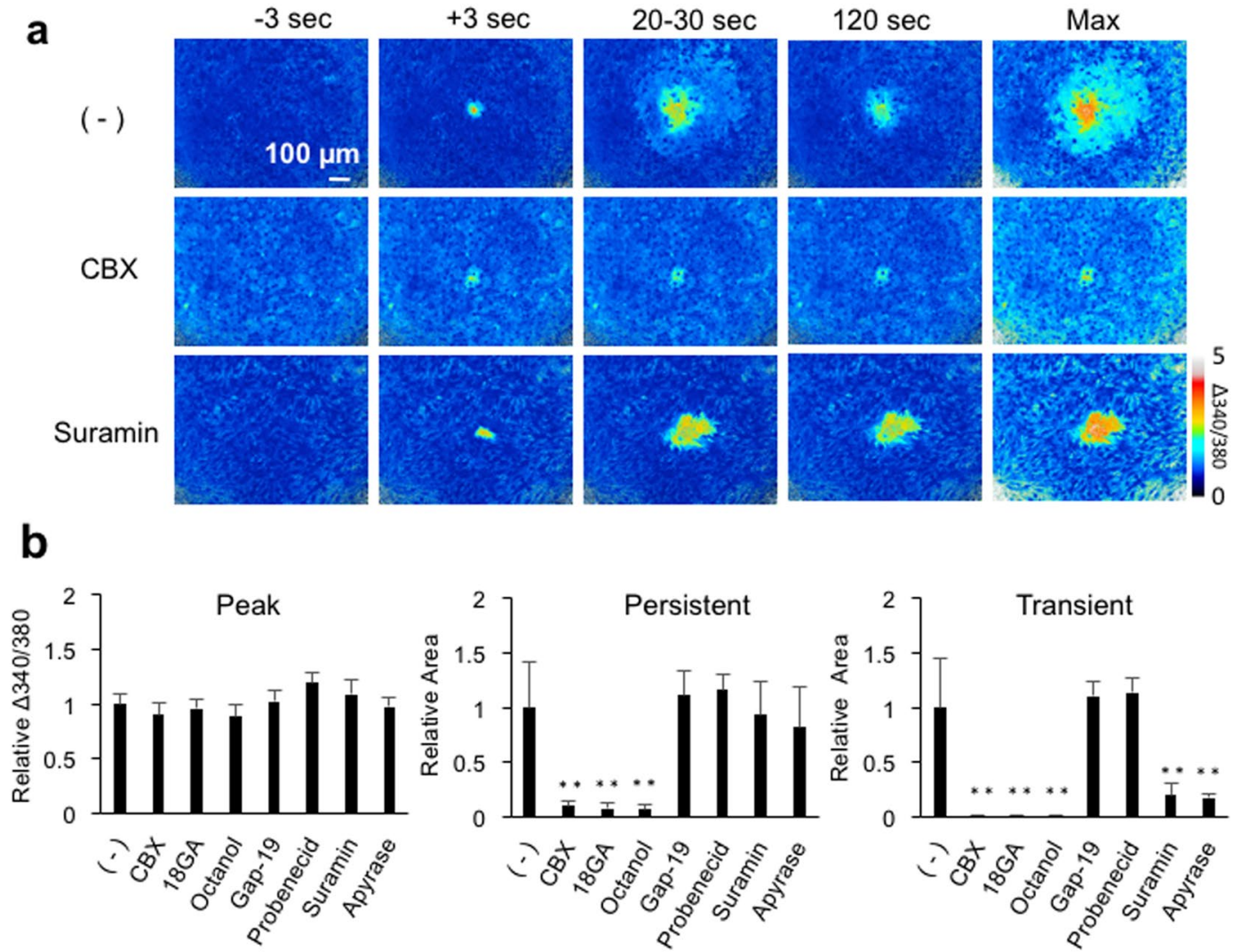

C
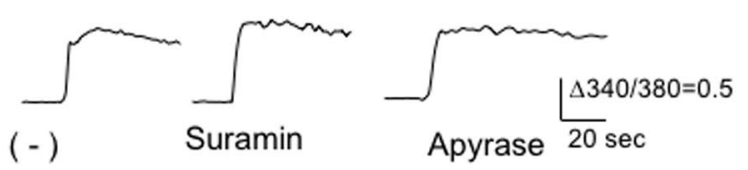

e

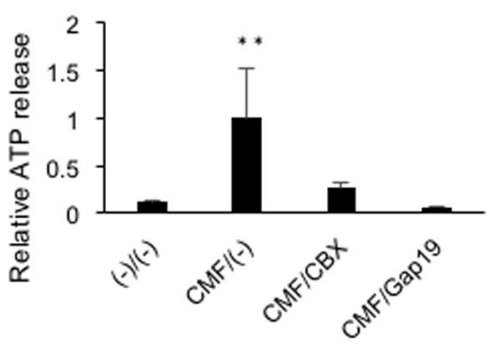

Figure 4. Pharmacologic characterization of calcium wave propagation. Astrocytes were treated with $100 \mu \mathrm{M}$ carbenoxolone (CBX), $100 \mu \mathrm{M} 18 \beta$-glycyrrhetinic acid (183GA), $1 \mathrm{mM}$ octanol, $300 \mu \mathrm{M}$ gap-19, $1 \mathrm{mM}$ probenecid, $100 \mu \mathrm{M}$ suramin or $15 \mathrm{unit} / \mathrm{ml}$ apyrase for $10 \mathrm{~min}$ prior to mechanical stimulation. (a) Representative calcium waves of control (-), CBX-and suramin-treated cells. (b) Amplitudes of the peak $\left[\mathrm{Ca}^{2+}\right]_{\mathrm{i}}$ increases, and areas of the persistent and transient $\left[\mathrm{Ca}^{2+}\right]_{\mathrm{i}}$ increases normalized to control. $\mathrm{n}=8$ experiments; ${ }^{* *} \mathrm{p}<0.01$ versus $(-)$, Bonferroni's multiple comparison test after one-way ANOVA. (c) Representative persistent $\left[\mathrm{Ca}^{2+}\right]_{\mathrm{i}}$ increases in individual cells of control, suramin- and apyrase-treated cultures. (d) Quantification of $\left[\mathrm{Ca}^{2+}\right]_{\mathrm{i}}$ increases in the region of persistent $\left[\mathrm{Ca}^{2+}\right]_{\mathrm{i}}$ increases, as shown by the area under the curve (AUC) and the peak amplitude (Peak) for $70 \mathrm{sec}$ after mechanical stimulation, normalized to control. $\mathrm{n}=15$ cells from three independent experiments. No significant difference was observed by one-way ANOVA. (e) Effects of CBX and gap-19 on ATP release via gap junction hemichannels activated by treatment with calcium-magnesium free (CMF) medium. ATP in the extracellular solution $10 \mathrm{~min}$ after pharmacologic treatment was measured by luciferase assays and normalized to $\mathrm{CMF} /(-) . \mathrm{n}=3$ wells; $* * \mathrm{p}<0.0101$ versus $(-) /$ $(-)$, Bonferroni's multiple comparison test after one-way ANOVA.

The effects of omitting extracellular $\mathrm{Ca}^{2+}$ on calcium waves were further analyzed. A representative $\left[\mathrm{Ca}^{2+}\right]_{\mathrm{i}}$ increase in an individual cell treated with $\mathrm{Ca}^{2+}$-free medium was transient similar to that in the distal region of control (Fig. 3c). The velocity of calcium wave in the $\mathrm{Ca}^{2+}$-free group $(9.1 \pm 1.8 \mu \mathrm{m} / \mathrm{sec})$ were similar to that of the transient $\left[\mathrm{Ca}^{2+}\right]_{\mathrm{i}}$ increases in the control group $(9.3 \pm 1.6 \mu \mathrm{m} / \mathrm{sec})$, with both being significantly lower than the 

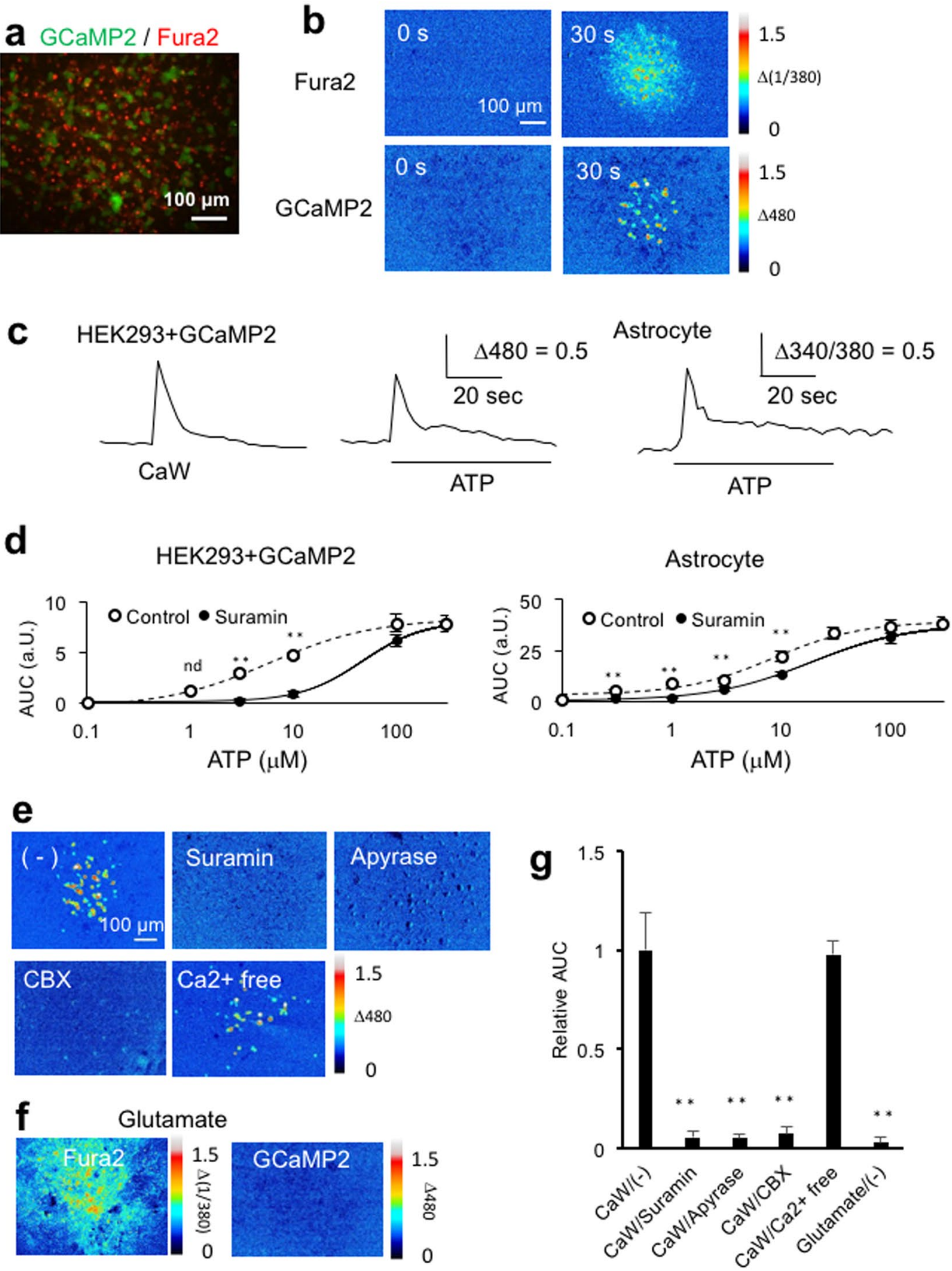

Figure 5. Pharmacologic characterizations of ATP release during calcium waves using HEK293 + GCaMP2 cells. Calcium waves and ATP release were simultaneously imaged as fluorescence changes in Fura2-loaded astrocytes and in HEK293 + GCaMP2 cells placed on the astrocytes, respectively. (a) Representative fluorescence images of Fura2-loaded astrocytes (Ex/Em $=380 / 535$, red) and HEK293 + GCaMP2 cells (Ex/Em = 480/535, green). (b) Representative images of $\left[\mathrm{Ca}^{2+}\right]_{\mathrm{i}}$ increases in astrocytes (Fura2) and HEK293 + GCaMP2 cells (GCaMP2) 0 and $30 \mathrm{sec}$ after mechanical stimulation. (c) Representative $\left[\mathrm{Ca}^{2+}\right]_{\mathrm{i}}$ increases in individual HEK293 + GCaMP2 cells and astrocyte during a calcium wave $(\mathrm{CaW})$ and following ATP treatment $(10 \mu \mathrm{M}$, bar). Cells were stimulated to induce calcium waves and then treated with ATP by bath loading. ATP responses of astrocytes and HEK293 + GCaMP were indistinguishable between areas with or without the calcium wave. (d) Concentration dependence of ATP-induced $\left[\mathrm{Ca}^{2+}\right]_{\mathrm{i}}$ increases in HEK293 + GCaMP2 cells and astrocytes in the presence and absence of suramin $(100 \mu \mathrm{M})$. The AUC of $\left[\mathrm{Ca}^{2+}\right]_{\mathrm{i}}$ increase was calculated during treatment with ATP for $1 \mathrm{~min}$. $\mathrm{n}=28-30$ cells from three independent experiments; $* * \mathrm{p}<0.01$ between control and the suramintreated group at each ATP concentration, Bonferroni's multiple comparison test after one-way ANOVA. 
(e) Representative maximum $\left[\mathrm{Ca}^{2+}\right]_{\mathrm{i}}$ projections of HEK293 + GCaMP2 for 2 min after mechanical stimulation with or without pharmacologic treatment. (f) Representative maximum $\left[\mathrm{Ca}^{2+}\right]_{\mathrm{i}}$ projection of an astrocyte (Fura2) and HEK293 + GCaMP2 (GCaMP2) during 2 min of treatment with $100 \mu \mathrm{M}$ glutamate. (g) AUCs of $\left[\mathrm{Ca}^{2+}\right]_{\mathrm{i}}$ increases in HEK293 + GCaMP2 for 2 min after mechanical stimulation $(\mathrm{CaW})$ or glutamate treatment with or without pharmacologic treatments. $\mathrm{n}=28-30$ cells from four independent experiments; $* * \mathrm{p}<0.01$ versus $\mathrm{CaW} /(-)$, Bonferroni's multiple comparison test after oneway ANOVA.

velocity of the persistent $\left[\mathrm{Ca}^{2+}\right]_{\mathrm{i}}$ increase in the control group $(22.6 \pm 2.9 \mu \mathrm{m} / \mathrm{sec})(\mathrm{Fig} .3 \mathrm{~d})$. These results indicate that extracellular $\mathrm{Ca}^{2+}$ does not affect the propagations of the transient $\left[\mathrm{Ca}^{2+}\right]_{\mathrm{i}}$ increases.

Mechanisms of calcium wave propagation. The mechanisms underlying calcium wave propagation were pharmacologically examined by treating cells with the gap junction blockers, $100 \mu \mathrm{M}$ carbenoxolone (CBX), $100 \mu \mathrm{M} 18 \beta$-glycyrrhetinic acid (18GA) and $1 \mathrm{mM}$ octanol; a blocker of gap junction hemichannels containing connexin $43(\mathrm{Cx} 43)$, which is a major connexin subtype in cultured astrocytes ${ }^{22}, 300 \mu \mathrm{M}$ gap-1923; a pannexin hemichannel blocker, $1 \mathrm{mM}$ Probenecid; an ATP receptor antagonist, $100 \mu \mathrm{M}$ suramin; and an ATP degrading enzyme, $15 \mathrm{unit} / \mathrm{ml}$ apyrase. Figure 4 a shows representative calcium waves of control, CBX- and suramin-treated cells. These results indicate that CBX abolishes calcium waves without affecting the peak $\left[\mathrm{Ca}^{2+}\right]_{\mathrm{i}}$ increases, whereas suramin eliminates the transient $\left[\mathrm{Ca}^{2+}\right]_{\mathrm{i}}$ increases without affecting the peak or the persistent $\left[\mathrm{Ca}^{2+}\right]_{i}$ increases. Figure $4 \mathrm{~b}$ shows quantitative analyses of the calcium wave components. The peak $\left[\mathrm{Ca}^{2+}\right]_{\mathrm{i}}$ increases were not significantly affected by any pharmacologic treatments, indicating that they do not involve either gap junction or purinergic signaling. In contrast, CBX, 18GA and octanol significantly reduced areas of the persistent $\left[\mathrm{Ca}^{2+}\right]_{i}$ increases, to $10 \%, 8 \%$ and $7 \%$, respectively, and reduced areas of the transient $\left[\mathrm{Ca}^{2+}\right]_{\mathrm{i}}$ increases to $1 \%, 1 \%$ or $0.8 \%$, respectively, indicating that gap junctions are essential for calcium waves. Gap-19 and probenecid did not affect either the persistent or transient $\left[\mathrm{Ca}^{2+}\right]_{\mathrm{i}}$ increases, indicating that connexin and pannexin hemichannels are not involved in calcium waves. Suramin and apyrase had no effect on areas of the persistent $\left[\mathrm{Ca}^{2+}\right]_{\mathrm{i}}$ increases, but significantly reduced areas of the transient $\left[\mathrm{Ca}^{2+}\right]_{\mathrm{i}}$ increases to $20 \%$ or $18 \%$, respectively, suggesting that purinergic signaling is involved in the generation and/or propagation of transient $\left[\mathrm{Ca}^{2+}\right]_{\mathrm{i}}$.

The effects of purinergic inhibitors on the persistent $\left[\mathrm{Ca}^{2+}\right]_{\mathrm{i}}$ increases were further analyzed. Individual astrocytes showed persistent $\left[\mathrm{Ca}^{2+}\right]_{\mathrm{i}}$ increases, regardless of the presence of purinergic inhibitors (Fig. $4 \mathrm{c}$ ). The extent of $\left[\mathrm{Ca}^{2+}\right]_{\mathrm{i}}$ increases, expressed as peak amplitude (peak) or area under the curve (AUC), was not affected by these purinergic inhibitors (Fig. 4d), indicating that purinergic signaling is not involved in the persistent $\left[\mathrm{Ca}^{2+}\right]_{\mathrm{i}}$ increases.

The inhibition of astrocyte gap junction hemichannels by gap-19 was confirmed by measuring ATP release, using luciferase assays, following treatment in $\mathrm{Ca}^{2+}$ and $\mathrm{Mg}^{2+}$ free (CMF) medium, which is commonly used to induce the release of macromolecules from gap junction hemichannels ${ }^{24}$. As expected, CMF enhanced extracellular ATP, but this increase was significantly reduced to $4 \%$ and $10 \%$ by CBX and gap-19, respectively (Fig. 4e), indicating that gap-19 potently inhibits astrocyte gap junction hemichannels. These findings confirmed that calcium waves do not involve ATP release via gap junction hemichannels.

ATP release mechanisms in calcium waves. ATP release during the propagation of astrocyte calcium waves was investigated using an ATP sniffing cell, HEK293 cells expressing a fluorescent $\mathrm{Ca}^{2+}$ indicator protein, GCaMP2 ${ }^{25}$. $\mathrm{P}_{2 \mathrm{Y} 1}$ and $\mathrm{P}_{2 \mathrm{Y} 4}$, but not $\mathrm{P}_{2 \mathrm{Y}}, \mathrm{P}_{2 \mathrm{Y} 6}$ or $\mathrm{P}_{2 \mathrm{X}}$ receptors are expressed in HEK293 cells and mediate ATP-induced $\left[\mathrm{Ca}^{2+}\right]_{\mathrm{i}}$ increases ${ }^{26}$. Meanwhile, cultured astrocytes express a variety of $\mathrm{P}_{2 \mathrm{X}}$ and $\mathrm{P}_{2 Y}$ receptors, but their ATP-induced $\left[\mathrm{Ca}^{2+}\right]_{\mathrm{i}}$ increases are largely mediated by $\mathrm{P}_{2 \mathrm{Y}}$ receptors, except $\mathrm{P}_{2 \times 7}$ receptor-mediated calcium influx in response to high concentrations of ATP ${ }^{27}$. Thus, it is assumed that HEK293 + GCaMP2 cells adjacent to astrocytes show $\left[\mathrm{Ca}^{2+}\right]_{\mathrm{i}}$ increases in response to extracellular ATP mediating astrocyte calcium waves. HEK293 + GCaMP2 cells were placed on top of Fura2-loaded astrocytes for simultaneous imaging of $\left[\mathrm{Ca}^{2+}\right]_{\mathrm{i}}$ in both cell types (Fig. 5a). HEK293 + GCaMP2 cells were seeded sparsely enough to avoid transmissions of $\left[\mathrm{Ca}^{2+}\right]_{\mathrm{i}}$ increases by their own gap junctions. Mechanical stimulation of astrocytes induced $\left[\mathrm{Ca}^{2+}\right]_{\mathrm{i}}$ increases in HEK293 + GCaMP2 cells, in areas equivalent to those of astrocyte calcium waves (Fig. 5b). To interpret these findings, the characteristics of $\left[\mathrm{Ca}^{2+}\right]_{i}$ increases in HEK293 + GCaMP2 cells were analyzed. Transient $\left[\mathrm{Ca}^{2+}\right]_{\mathrm{i}}$ increases, which are characteristic of astrocyte $\left[\mathrm{Ca}^{2+}\right]_{\mathrm{i}}$ increases in the distal region, were induced in HEK293 + GCaMP2 cells by astrocyte calcium waves and ATP, as well as in astrocytes by ATP (Fig. 5c), indicating that the temporal dynamics of GCaMP2-expressing HEK293 cells is comparable to that of Fura2-loaded astrocytes. The $\mathrm{EC}_{50}$ values of HEK293 + GCaMP2 cells and astrocytes to ATP were $5.9 \mu \mathrm{M}$ and $8.5 \mu \mathrm{M}$, respectively (Fig. 5d). Addition of $100 \mu \mathrm{M}$ suramin significantly reduced the $\left[\mathrm{Ca}^{2+}\right]_{\mathrm{i}}$ increases in both cell types induced by $\leq 10 \mu \mathrm{M}$ ATP. Thus, HEK293 + GCaMP2 cells and astrocytes respond to ATP in the same concentration range, and these responses are similarly sensitive to suramin, suggesting that HEK293 + GCaMP2 cells detect extracellular ATP with the same sensitivity as astrocytes.

Pharmacologic analysis of $\left[\mathrm{Ca}^{2+}\right]_{\mathrm{i}}$ increases by HEK293 + GCaMP2 cells during astrocyte calcium waves showed that these GCaMP2 responses were significantly reduced by suramin and apyrase, to 5\% and 7\%, respectively, confirming that they reflect astrocyte ATP releases (Fig. $5 \mathrm{e}$ and g). CBX, which abrogated calcium waves, reduced the GCaMP2 response to 7\%, suggesting that interactions between astrocytes via gap junctions is essential for ATP release, and that extracellular ATP released during calcium waves is not likely due to mechanically-stimulated astrocytes alone. $\mathrm{Ca}^{2+}$-free medium, which abrogated the persistent $\left[\mathrm{Ca}^{2+}\right]_{\mathrm{i}}$ increases without affecting the peak and transient $\left[\mathrm{Ca}^{2+}\right]_{\mathrm{i}}$ increases, had no effect on GCaMP2 responses even in the 

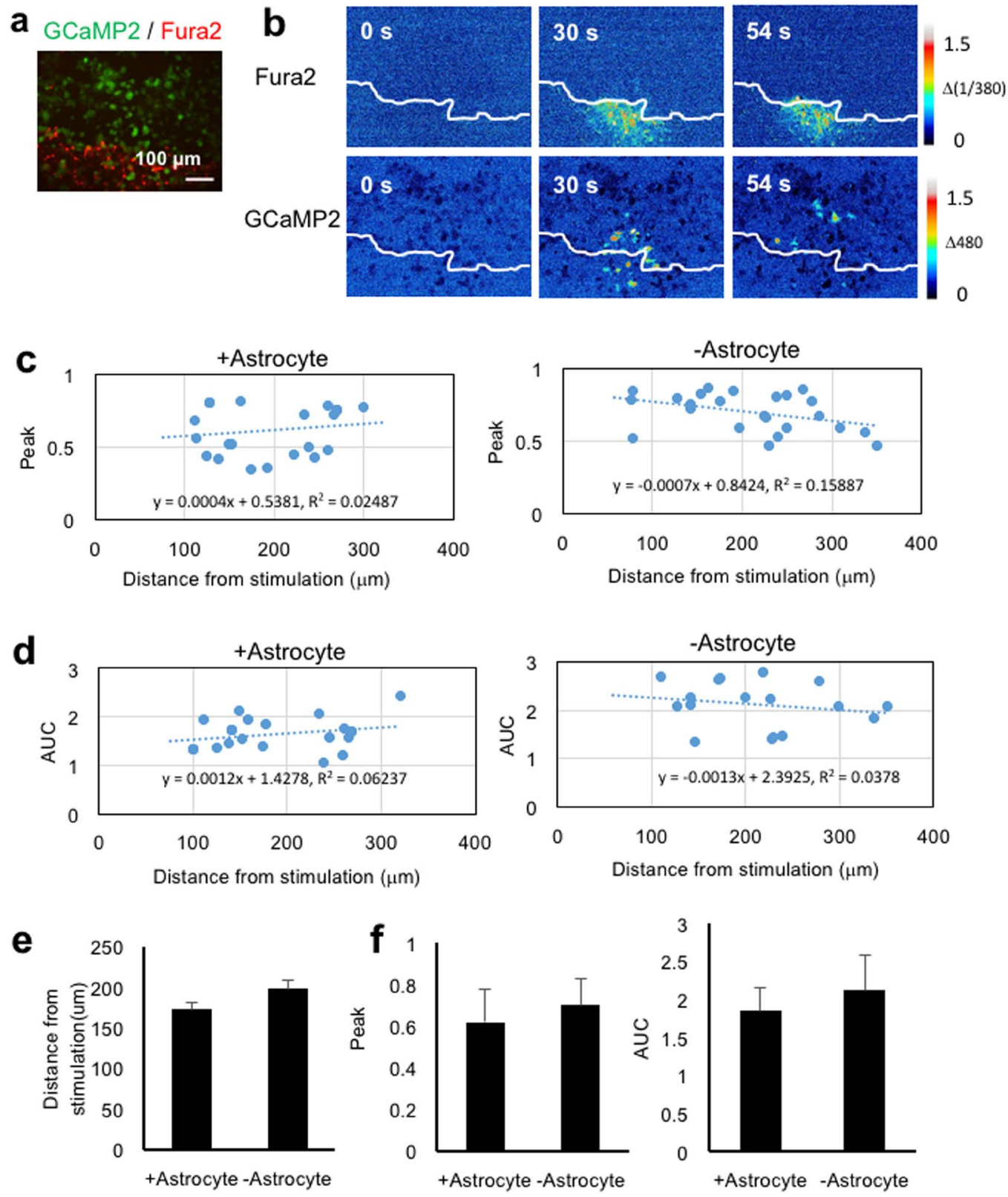

Figure 6. Distribution of extracellular ATP during calcium waves. Fura2-loaded astrocytes were scratched to create astrocyte-free areas, followed by seeding of HEK293 + GCaMP2 cells and mechanical stimulation of astrocytes close to the astrocyte-free area. (a) Representative fluorescence image of Fura2-loaded astrocytes (red) and HEK293 + GCaMP2 cells (green). (b) Representative images of $\left[\mathrm{Ca}^{2+}\right]_{\mathrm{i}}$ increases in astrocytes (Fura2) and HEK293 + GCaMP2 cells (GCaMP2) at 0,30 and $54 \mathrm{sec}$ after mechanical stimulation. The border of the astrocyte-free area in each panel is indicated by a white line. HEK293 + GCaMP2 cells showing $25-50 \%\left[\mathrm{Ca}^{2+}\right]_{\mathrm{i}}$ increases were used in the following analyses: (c),(d) Distributions of peak amplitudes and AUCs of $\left[\mathrm{Ca}^{2+}\right]_{\mathrm{i}}$ increases in HEK293 + GCaMP2 cells on astrocytes (+Astrocyte) and on astrocyte-free areas (-Astrocyte), plotted against the distances between HEK293 + GCaMP2 cells and stimulated astrocytes. Regression lines are shown as dotted lines. The regression equation and correlation coefficient $\left(\mathrm{R}^{2}\right)$ are included in each panel. Results are representative of four independent experiments. (e) Distances between HEK293 + GCaMP2 cells and stimulated astrocytes in the presence or absence of astrocytes. $n=32$ cells from four independent experiments. (f) Peak amplitudes and AUCs of HEK293 + GCaMP2 cells in the presence and absence of astrocytes. $n=32$ cells from four independent experiments. No significant difference was observed by Student's t-test.

proximal region, confirming that the propagation of the transient $\left[\mathrm{Ca}^{2+}\right]_{\mathrm{i}}$ increases was mediated by extracellular ATP and suggesting that the persistent $\left[\mathrm{Ca}^{2+}\right]_{\mathrm{i}}$ increases in the proximal region, which is larger than the transient $\left[\mathrm{Ca}^{2+}\right]_{\mathrm{i}}$ increases are not essential for ATP release. The finding, that ATP release is independent of $\left[\mathrm{Ca}^{2+}\right]_{i}$ increase, was further strengthened by results showing that $100 \mu \mathrm{M}$ glutamate induced robust $\left[\mathrm{Ca}^{2+}\right]_{\mathrm{i}}$ increases in 

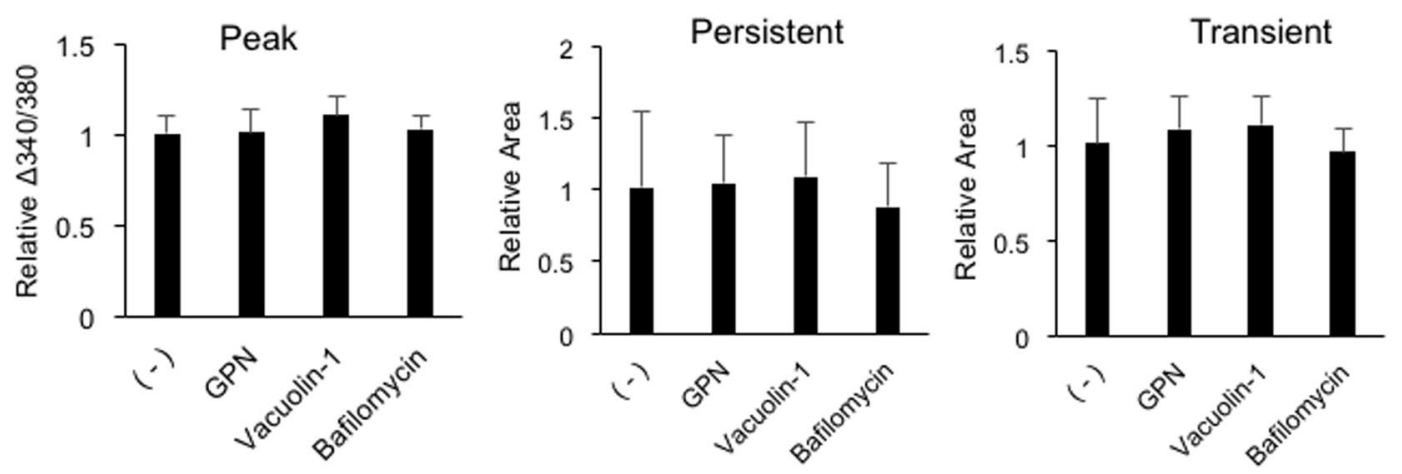

Figure 7. Effects of exocytosis inhibitors on calcium waves. Astrocytes were treated with $200 \mu \mathrm{M}$ GPN or $2 \mu \mathrm{M}$ bafilomycin for $1 \mathrm{~h}$ or with $10 \mu \mathrm{M}$ vacuolin- 1 for $10 \mathrm{~min}$, followed by mechanical stimulation. Amplitudes of the peak $\left[\mathrm{Ca}^{2+}\right]_{\mathrm{i}}$ increases, and areas of the persistent and transient $\left[\mathrm{Ca}^{2+}\right]_{\mathrm{i}}$ increases are plotted normalized to control. $\mathrm{n}=8$ experiments. No significant difference was observed by one-way ANOVA.

astrocytes, but failed to induce GCaMP2 responses (Fig. $5 \mathrm{f}$ and $\mathrm{g}$ ). These results indicate that $\left[\mathrm{Ca}^{2+}\right]_{\mathrm{i}}$ increases do not trigger astrocyte ATP release.

Extracellular ATP diffusion during calcium waves. To monitor extracellular ATP diffusion during calcium waves, the GCaMP2 responses of astrocyte-free areas, generated by scratching astrocyte monolayers with a needle, were examined. Figure $6 \mathrm{a}$ is a representative fluorescence image of Fura2-loaded astrocytes after scratching and seeding HEK293 + GCaMP2 cells. Mechanical stimulation induced an astrocyte calcium wave and GCaMP2 responses in both astrocytes and astrocyte-free areas (Fig. 6b). HEK293 + GCaMP2 cells with $\left[\mathrm{Ca}^{2+}\right]_{\mathrm{i}}$ increases $25-50 \%$ of the highest $\left[\mathrm{Ca}^{2+}\right]_{\mathrm{i}}$ increase adjacent to stimulated astrocytes were subjected to further analysis for determining the influence of astrocytes on extracellular ATP diffusion. HEK293 + GCaMP2 cells with $\left[\mathrm{Ca}^{2+}\right]_{\mathrm{i}}$ increases $>50 \%$ were excluded because these cells were mostly present in astrocyte-containing proximal regions. HEK293 + GCaMP2 cells with $\left[\mathrm{Ca}^{2+}\right]_{\mathrm{i}}$ increases $<25 \%$ were also excluded, because of their sparse distribution. When peak amplitudes (Fig. 6C) and AUCs (Fig. 6d) of $\left[\mathrm{Ca}^{2+}\right]_{\mathrm{i}}$ increases in individual HEK293 + GCaMP2 cells showing 25-50\% increases in $\left[\mathrm{Ca}^{2+}\right]_{\mathrm{i}}$ were plotted against the distance from the stimulated astrocyte, these HEK293 + GCaMP2 cells were found to be located approximately 100-300 $\mu \mathrm{m}$ from stimulated astrocytes, indicating that these cells were in the distal region. Their magnitude of $\left[\mathrm{Ca}^{2+}\right]_{\mathrm{i}}$ increase did not correlate with distance ( $\mathrm{R}^{2}$ values were not significant) both in the presence and absence of astrocytes. The mean distances between stimulated astrocytes and HEK293 + GCaMP2 cells showing 25-50\% increases in $\left[\mathrm{Ca}^{2+}\right]_{\mathrm{i}}$ and the amplitudes and AUC of their $\left[\mathrm{Ca}^{2+}\right]_{\mathrm{i}}$ increases were not affected by the presence of astrocytes (Fig. $6 \mathrm{e}$ and $\mathrm{f}$ ). These results indicate that the GCaMP2 responses do not decline in the distal region, and are not affected by the presence of astrocytes. These findings therefore suggest that the transient $\left[\mathrm{Ca}^{2+}\right]_{\mathrm{i}}$ increases in the distal region is attributed to the diffusion of ATP released in the proximal region. Since HEK293 + GCaMP2 cell responses did not decline depending on the distance, the concentration of flowing extracellular ATP was likely constant, presumably due to continuous release, rather than diffusion of transiently-released ATP with dilution.

ATP release Mechanisms in calcium waves. ATP release mechanisms underlying calcium waves were explored pharmacologically. To assess the involvement of lysosome exocytosis, which was suggested to be the ATP release mechanism during electrically-induced calcium waves in cultured astrocytes ${ }^{28}$, astrocytes were treated with a cathepsin C substrate, $200 \mu \mathrm{M}$ glycyl-L-phenylalanine 2-naphthylamide (GPN), or a cell permeable triadin, $10 \mu \mathrm{M}$ vacuolin-1, which reduce lysosomes. In addition, cells were treated with $2 \mu \mathrm{M}$ bafilomycin, an inhibitor of vesicular ATPase that depletes vesicles for exocytosis. None of these inhibitors had any effect on the components of calcium waves, indicating that neither lysosome nor conventional exocytosis was involved in ATP release during calcium waves (Fig. 7). The involvement of volume regulated anion channels (VRACs) was also assessed by incubation with the VRAC blockers, $20 \mu \mathrm{M}$ 4-[(2-Butyl-6,7-dichloro-2-cyclopentyl-2,3-dihydro-1-oxo$1 \mathrm{H}$-inden-5-yl)oxy]butanoic acid (DCPIB) and $200 \mu \mathrm{M}$ diisothiocyano-2,2'-stilbenedisulfonic acid (DIDS). Neither of these reagents affected the peak or persistent $\left[\mathrm{Ca}^{2+}\right]_{\mathrm{i}}$ increases, whereas both significantly reduced the transient $\left[\mathrm{Ca}^{2+}\right]_{\mathrm{i}}$ increases to $4 \%$ and $14 \%$, respectively (Fig. 8a), suggesting that VRAC blockers eliminate ATP release. The effects of these VRAC blockers on astrocyte ATP releases were examined using HEK293 + GCaMP2 cells and luciferase assays. Both DCPIB and DIDS significantly reduced the GCaMP2 responses, to $6 \%$ and $2 \%$, respectively (Fig. 8b). In the luciferase assays, astrocyte ATP release was induced mechanically by dropping glass beads, which was reported to induce astrocyte calcium waves similar to the method of induction by glass pipettes ${ }^{19}$. Because ATP releases during calcium waves measured by HEK293 + GCaMP2 assays were eliminated by CBX, the effects of gap junction, gap junction hemichannel, and VRAC blockers were tested. DCBPI, DIDS and CBX significantly reduced beads-induced ATP release to $16 \%, 18 \%$ and $15 \%$, respectively, whereas gap- 19 had no effect (Fig. 8c). DCPIB was reported to inhibit Cx43 hemichannel ${ }^{29}$, however the effects of DCPIB on calcium waves and beads-induced ATP release are not mediated by $\mathrm{Cx} 43$ hemichannel, because both were not affected by the $\mathrm{Cx} 43$ hemichannel selective inhibitor, gap-19. These results indicate that VRAC blockers eliminate 
a

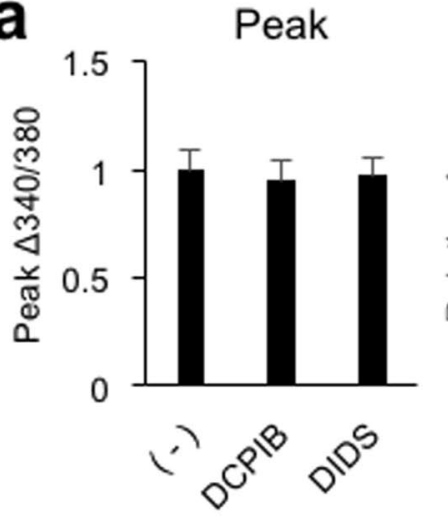

b HEK293+GCaMP
Persistent

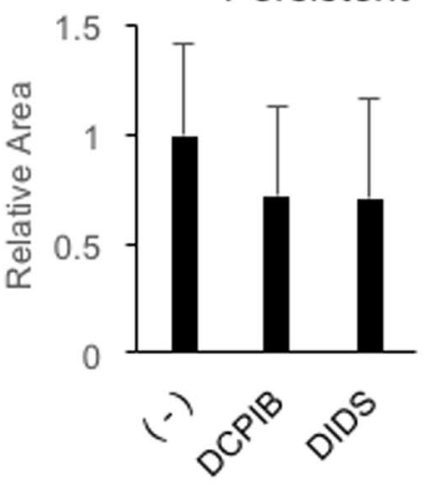

C Luciferase assay
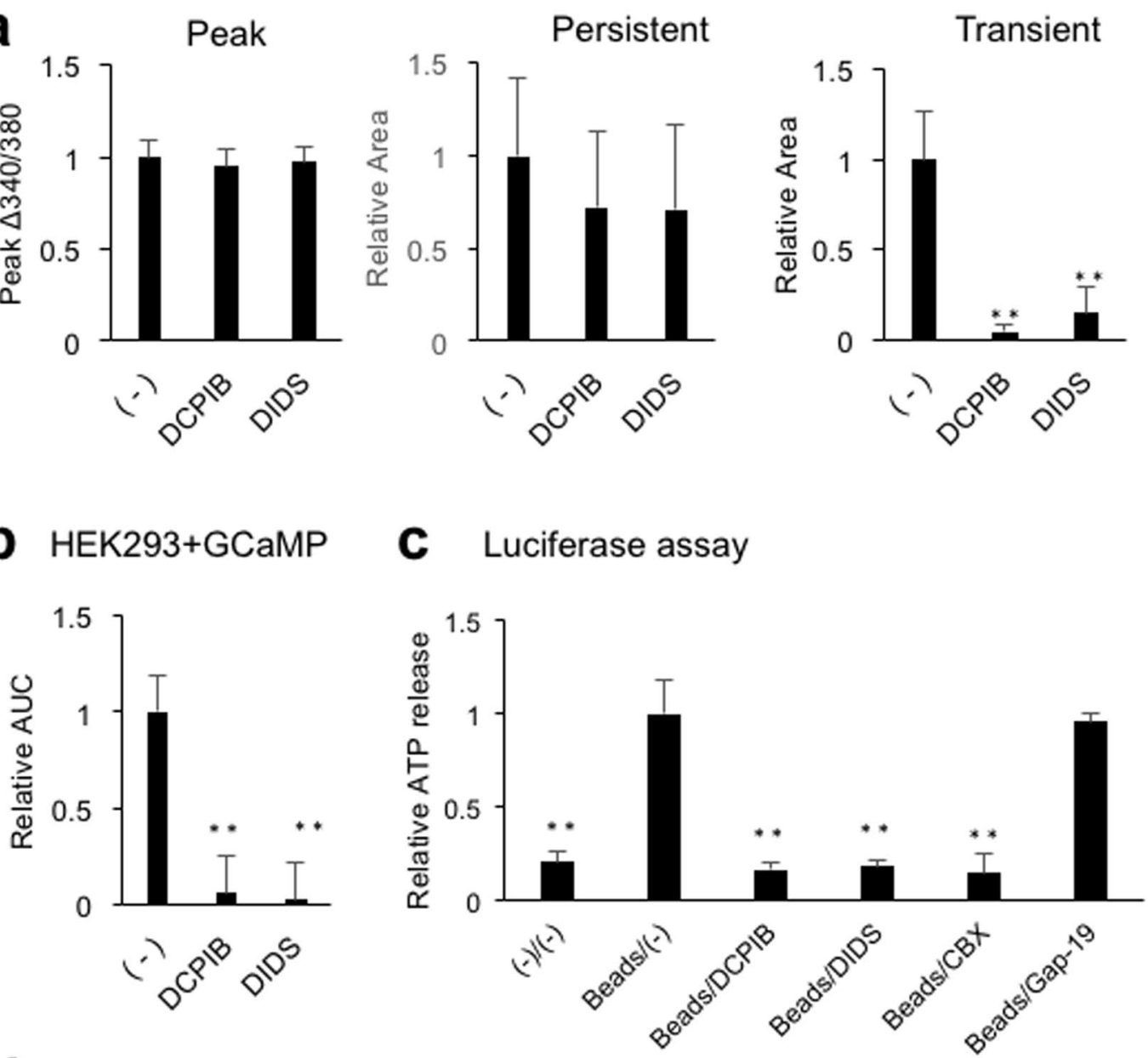

d Luciferase assay

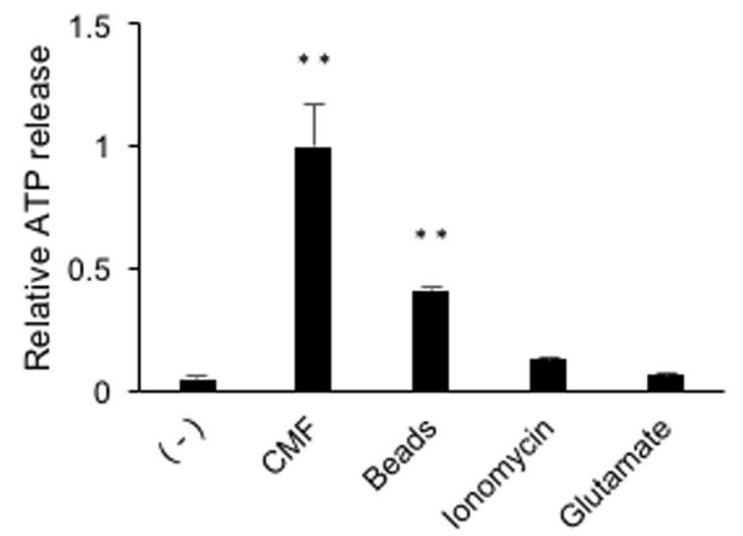

Figure 8. Effects of VRAC inhibitors on calcium waves and ATP release. Astrocytes were treated with 20 $\mu \mathrm{M}$ DCPIB or $200 \mu \mathrm{M}$ DIDS for $10 \mathrm{~min}$ prior to mechanical stimulations. (a) Effects of VRAC inhibitors on amplitudes of the peak $\left[\mathrm{Ca}^{2+}\right]_{\mathrm{i}}$ increases and areas of the persistent and transient $\left[\mathrm{Ca}^{2+}\right]_{\mathrm{i}}$ increases, normalized to control. $\mathrm{n}=8$ experiments; ${ }^{* *} \mathrm{p}<0.01$ versus $(-)$, Bonferroni's multiple comparison test after one-way ANOVA. (b) Effects of VRAC inhibitors on ATP release measured by HEK293 + GCaMP2 cells. AUCs of $\left[\mathrm{Ca}^{2+}\right]_{\mathrm{i}}$ increases in HEK293 + GCaMP2 cells for $2 \mathrm{~min}$ after mechanical stimulation, normalized to control. $\mathrm{n}=32$ cells from four independent experiments; $* * \mathrm{p}<0.01$ versus $(-)$, Bonferroni's multiple comparison test after one-way ANOVA. (c) Effects of VRAC inhibitors on ATP release measured by luciferase assay. Cells were mechanically stimulated by dropping $0.02 \mathrm{~g}$ glass beads $(30-50 \mu \mathrm{m}$ in diameter); extracellular solution was collected 10 min later and used for luciferase assays. $\mathrm{n}=3$ wells; $* * \mathrm{p}<0.01$ versus Beads/( -$)$, Bonferroni's multiple comparison test after one-way ANOVA. (d) Comparison of ATP release pathways measured by luciferase assays. Astrocytes were stimulated by CMF, beads, $100 \mu \mathrm{M}$ ionomycin, and $1 \mathrm{mM}$ glutamate. $\mathrm{n}=3$ wells; $* * \mathrm{p}<0.01$ versus $(-)$, Bonferroni’s multiple comparison test after one-way ANOVA. 
propagations of the transient $\left[\mathrm{Ca}^{2+}\right]_{\mathrm{i}}$ increases by blocking mechanically-induced ATP release and that gap junctions are involved in mechanically-induced ATP release.

Finally, ATP release by CMF, beads, ionomycin and glutamate were compared quantitatively. The amount of ATP released by beads was $43 \%$ that by CMF, whereas neither $100 \mu \mathrm{M}$ ionomycin nor $1 \mathrm{mM}$ glutamate induced detectable ATP release (Fig. 8d). These results indicate that mechanically-induced ATP release via VRAC is comparable to the ATP released by gap junction hemichannels, whereas $\left[\mathrm{Ca}^{2+}\right]_{\mathrm{i}}$ does not induce release of ATP.

\section{Discussion}

The present study demonstrates that mechanically-induced astrocyte calcium waves consist of three components; (i) $\left[\mathrm{Ca}^{2+}\right]_{\mathrm{i}}$ increases in mechanically stimulated cells, which are independent of $\mathrm{Ca}^{2+}$ influx and IICR, (ii) fast propagation of persistent $\left[\mathrm{Ca}^{2+}\right]_{\mathrm{i}}$ increases in the proximal region, which are mediated by gap junctions and (iii) slow propagation of transient $\left[\mathrm{Ca}^{2+}\right]_{\mathrm{i}}$ increases in the distal region, which are mediated by extracellular ATP. These calcium waves also involve ATP release via VRAC activated by non- $\mathrm{Ca}^{2+}$ signal propagation via gap junctions in the proximal region.

The findings in the present study are in good agreement with those of previous studies. For example, the velocities of the calcium waves $(22.6 \pm 2.9 \mu \mathrm{m} / \mathrm{sec}$ in the proximal region and $9.3 \pm 1.6 \mu \mathrm{m} / \mathrm{sec}$ in the distal region) were equivalent to those previously reported, $20 \mu \mathrm{m} / \mathrm{sec}^{1}$ and $13.9 \mu \mathrm{m} / \mathrm{sec}^{30}$; and the radii of the distal region $(201 \mu \mathrm{m})$ were similar to those of previous reports, $204 \mu \mathrm{m}^{30}$ and $180 \mu \mathrm{m}^{2}$. Furthermore, the decline in calcium wave amplitudes and velocities during propagation ${ }^{2}$ and the discontinuous distribution of $\left[\mathrm{Ca}^{2+}\right]_{i}{ }^{16}$ were shown in previous studies on astrocyte calcium waves. However, to our knowledge, this is the first study demonstrating distinct components of astrocyte calcium waves, and showing different contributions of gap junction and extracellular ATP to calcium wave propagation by characterizing these components.

We also found that the peak $\left[\mathrm{Ca}^{2+}\right]_{i}$ increases were not affected by any pharmacologic inhibitors of $\left[\mathrm{Ca}^{2+}\right]_{\mathrm{i}}$ increase or propagation. The distinction we observed between the pharmacologic characteristics of peak $\left[\mathrm{Ca}^{2+}\right]_{i}$ and adjacent propagating $\left[\mathrm{Ca}^{2+}\right]_{\mathrm{i}}$ increases were consistent with those of previous studies, which showed that a PLC and a SERCA inhibitor eliminated propagating $\left[\mathrm{Ca}^{2+}\right]_{\mathrm{i}}$ increases in the calcium waves of airway epithelial cells $^{31}$ and smooth muscle cells ${ }^{32}$, respectively, without affecting the $\left[\mathrm{Ca}^{2+}\right]_{\mathrm{i}}$ increases in mechanically-stimulated cells. The lack of effect of the absence of extracellular $\mathrm{Ca}^{2+}$ on peak $\left[\mathrm{Ca}^{2+}\right]_{\mathrm{i}}$ increases excludes the possibility that touching with glass pipette tips induced the initial $\left[\mathrm{Ca}^{2+}\right]_{\mathrm{i}}$ increases by $\mathrm{Ca}^{2+}$ influx via mechanosensitive channels expressed in astrocytes ${ }^{33}$, or via physically-damaged plasma membranes. Since both omitting extracellular $\mathrm{Ca}^{2+}$ and inhibiting IICR did not affect increases in peak $\left[\mathrm{Ca}^{2+}\right]_{\mathrm{i}}$, mechanical stimulation may induce $\mathrm{Ca}^{2+}$ release from thapsigargin-insensitive calcium stores, which are not involved in $\operatorname{IICR}^{34,35}$.

The persistent $\left[\mathrm{Ca}^{2+}\right]_{\mathrm{i}}$ increases, which were sustained in the proximal region for several minutes, were larger and propagated faster than the transient $\left[\mathrm{Ca}^{2+}\right]_{\mathrm{i}}$ increases. Since these $\left[\mathrm{Ca}^{2+}\right]_{\mathrm{i}}$ increases were eliminated by IICR inhibitors and by omitting extracellular $\mathrm{Ca}^{2+}$, they may be shaped synergistically by IICR and $\mathrm{Ca}^{2+}$ influx. The induction of $\mathrm{IP}_{3}$ by mechanical stimulation has been demonstrated pharmacologically in many cell types including astrocytes ${ }^{31,36}$. Theoretical studies have suggested that $\mathrm{IP}_{3}$ mobilization through gap junctions is the main pathway of astrocyte calcium waves, and that the regenerative production of $\mathrm{IP}_{3}$ by $\mathrm{Ca}^{2+}$ dependent PLC subtypes drives the propagation ${ }^{17,37}$. Regenerative $\mathrm{IP}_{3}$ production likely underlies the persistent $\left[\mathrm{Ca}^{2+}\right]_{\mathrm{i}}$ increases and the gap junction-mediated propagation of calcium waves. It may also be essential for ATP release in the proximal region, whereas the $\mathrm{IP}_{3}$ production for the transient $\left[\mathrm{Ca}^{2+}\right]_{\mathrm{i}}$ increases, which was mediated by $\mathrm{P}_{2 \mathrm{Y}}$ receptors, was not amplified by $\mathrm{Ca}^{2+}$-dependent PLC or capable of inducing ATP release.

Omitting extracellular $\mathrm{Ca}^{2+}$ eliminated the persistent $\left[\mathrm{Ca}^{2+}\right]_{\mathrm{i}}$ increases, indicating that the difference between the persistent and transient $\left[\mathrm{Ca}^{2+}\right]_{\mathrm{i}}$ increases was due to $\mathrm{Ca}^{2+}$ influx. Our attempts to pharmacologically identify calcium channels responsible for $\mathrm{Ca}^{2+}$ influx have been unsuccessful. Purinergic inhibitors did not influence persistent $\left[\mathrm{Ca}^{2+}\right]_{\mathrm{i}}$ increases, whereas HEK293 + GCaMP2 cells detected extracellular ATP in the proximal region. These findings suggested that ATP occupies ATP receptors, but that ATP-induced IICR is occluded by the large persistent $\left[\mathrm{Ca}^{2+}\right]_{\mathrm{i}}$ increases in the proximal region. Omitting extracellular $\mathrm{Ca}^{2+}$ likely eliminated these large persistent $\left[\mathrm{Ca}^{2+}\right]_{i}$ increases, allowing detection of ATP-induced IICR in the proximal region.

Because the transient $\left[\mathrm{Ca}^{2+}\right]_{\mathrm{i}}$ increases are abrogated by purinergic inhibitors and are insensitive to extracellular $\mathrm{Ca}^{2+}$, these increases have been attributed to ATP-induced IICR. The finding, that extracellular ATP in the distal region, as measured by HEK293 + GCaMP2 during calcium waves, was preserved even when astrocytes were removed by scratching, suggested that ATP is released within the proximal region and passively diffuses into the distal region as a continuous flow. These findings contradict a previous hypothesis, that ATP is released by a $\mathrm{Ca}^{2+}$-dependent regenerative process during propagation ${ }^{14}$. The lack of a regenerative process likely accounts for the lower velocity in the distal region. That is, $\left[\mathrm{Ca}^{2+}\right]_{\mathrm{i}}$ increases in the proximal region propagate rapidly and effectively by direct intracellular communications via gap junctions and regenerative $\mathrm{IP}_{3}$ production. In contrast, $\left[\mathrm{Ca}^{2+}\right]_{\mathrm{i}}$ increases in the distal region propagate slowly and passively by diffusion of ATP.

HEK293 + GCaMP2 cells, which are equivalent in sensitivity and pharmacologic properties to astrocytes in detecting extracellular ATP, were used in the present study to measure ATP release during calcium waves. Our findings, that purinergic inhibitors abolished GCaMP2 responses without affecting astrocyte $\left[\mathrm{Ca}^{2+}\right]_{\mathrm{i}}$ increases in the proximal region, suggested that extracellular ATP transmits $\left[\mathrm{Ca}^{2+}\right]_{\mathrm{i}}$ increases between astrocytes and HEK293 + GCaMP2. Moreover, the ability of CBX to abolish GCaMP2 responses suggests the involvement of gap junctions in ATP release. These findings, together with results showing that exogenous expression of connexin potentiated ATP release via anion channels ${ }^{38}$, indicate that VRAC is activated by a signal mediated by gap junctions. This signal is not likely to be $\left[\mathrm{Ca}^{2+}\right]_{\mathrm{i}}$, because (i) $\mathrm{Ca}^{2+}$-free medium reduced proximal $\left[\mathrm{Ca}^{2+}\right]_{\mathrm{i}}$ increases without affecting ATP release measured by GCaMP2 responses; (ii) glutamate induced robust $\left[\mathrm{Ca}^{2+}\right]_{\mathrm{i}}$ increases in astrocytes but not in adjacent HEK293 + GCaMP2 cells, and (iii) glutamate and ionomycin did not 
induce ATP releases detectable by luciferase assays. The $\mathrm{Ca}^{2+}$ independent ATP release during astrocyte calcium waves is consistent with previous imaging of extracellular ATP by luciferase ${ }^{36}$. In addition, Bergman glia were shown to release glutamate via DIDS-sensitive anion channels following optogenetic stimulation ${ }^{39}$, suggesting the possibility that depolarization and/or associated movement of ions trigger DIDS-sensitive release of anionic molecules.

Because ATP in astrocytes is involved in various intercellular communications, these cells are equipped with multiple ATP release mechanisms, including exocytosis, gap junction hemichannels, $\mathrm{P}_{2 \times 7}$ receptor and $\mathrm{VRAC}^{40}$. In the present study, luciferase assays showed substantial ATP release via gap junction hemichannels and VRAC, but not via exocytosis. GPN inhibition of lysosome exocytosis was reported to suppress ATP release during electrically-induced astrocyte calcium waves, which were potentiated by metabolic inhibition ${ }^{41}$. The lack of exocytosis in the present study may reflect differences in stimulation methods or culture conditions that affect metabolism, or the slow and ineffective progression of astrocyte exocytosis, as shown by total internal reflection fluorescence imaging ${ }^{42}$.

The protein, leucine-rich repeat containing 8 family member A (LRRC8A) was identified as a DCPIB-sensitive $\mathrm{VRAC}^{43,44}$. The involvement of LRRC8A in ATP release during astrocyte calcium wave propagation was examined using siRNA, however no significant influence of knocking-down LRRC8A was found (data not shown), suggesting the involvement of other unidentified VRAC genes. LRRC8A was found to be essential for glutamate release by astrocytes in response to ATP treatment or hypo-osmotic conditions ${ }^{45}$. However, most DCPIB-sensitive anion conduction in astrocytes has been associated with the release of glutamate, not ATP, although some glutamate release is triggered by ATP ${ }^{45,46}$. Mechanically-induced ATP release is thought to be due to other VRAC subtypes designated as maxi-anion channels ${ }^{47}$, which are also activated by mechanical stimulation including swelling by hypo-osmotic conditions. The gene encoding maxi-anion channels has not yet been identified. These channels are thought to possess a large pore, suitable for the permeation of ATP, which has a larger effective radius than glutamate $^{48}$. Thus, the VRAC genes involved in astrocyte calcium wave are yet to be determined.

The present study found that a single mechanical stimulation of an individual astrocyte induced ATP release via VRAC from adjacent astrocyte networks connected by gap junctions. This process may represent the initiation and/or propagation of pathological processes following brain injuries. Microglia co-cultured with astrocytes respond to adjacent astrocyte calcium waves by increasing $\left[\mathrm{Ca}^{2+}\right]_{\mathrm{i}}^{49}$ or releasing IL $1 \beta^{50}$. In vivo microglia adjacent to focal insults to brain parenchyma undergo structural changes in response to ATP released by astrocytes via a mechanism involving gap junctions $s^{51}$. This pathological activation of microglia is likely due to astrocyte release of ATP during calcium waves. Furthermore, blockers of $\mathrm{P}_{2 \mathrm{Y}}$ receptors, including suramin ${ }^{52,53}$, gap junctions ${ }^{54}$ and VRAC ${ }^{55}$ are neuroprotective after brain injury, strengthening the pathological implications of astrocyte ATP release. DCPIB has been reported to attenuate inflammatory responses after brain injury ${ }^{56}$. Further investigations based on the results of this study may identify the mechanically-induced signaling molecules, which propagate via gap junctions, and subsequent cascades for activating VRAC after mechanical stimulation, providing new insights into mechanisms of brain injury and possibly identifying therapeutic targets.

This detailed analysis of a classical model has revealed novel aspects of astrocyte physiology, especially the different contributions of two major pathways of calcium waves, gap junctions and extracellular ATP. The physiological and pathological implications of $\left[\mathrm{Ca}^{2+}\right]_{\mathrm{i}}$ dynamics and purinergic signaling of astrocytes remain incompletely understood. Addressing the mechanisms of action and functions of astrocyte $\left[\mathrm{Ca}^{2+}\right]_{\mathrm{i}}$, including calcium waves, calcium oscillation, and spontaneous $\left[\mathrm{Ca}^{2+}\right]_{\mathrm{i}}$ increases using cell culture models, remains important in basic and clinical research.

\section{Methods}

Cell culture. All animal experiments were approved by the Institutional Animal Care and Use Committee of Kobe University (Permission number: 25-20) and performed according to the Kobe University Animal Experimentation Regulations. Rats of either sex aged 0-2 postnatal days were sacrificed, and their cerebral cortices were removed and chopped into small pieces in Hank's Balanced Salt Solution (Thermo Fisher Scientific, Franklin, MA). Cell preparations were incubated with $0.25 \%$ trypsin (Worthington Biochem, Freehold, NJ), with occasional agitation, at $37^{\circ} \mathrm{C}$ for $20 \mathrm{~min}$. DNase (Sigma-Aldrich, St. Louis, MO) was added to a final concentration of $0.1 \%$ and the cell preparations were incubated at room temperature for $5 \mathrm{~min}$. The samples were transferred to Dulbecco's Modified Eagle's Medium containing 10\% fetal bovine serum (FBS, Nichirei Biosciences, Tokyo, Japan) and antibiotics $(50 \mu \mathrm{g} / \mathrm{ml}$ penicillin and $50 \mu \mathrm{g} / \mathrm{ml}$ streptomycin) and dispersed by pipetting. The resulting cells were seeded at $2.5 \times 10^{4}$ cells $/ \mathrm{cm}^{2}$ in $75 \mathrm{~cm}^{2}$ flasks and cultured in the presence of $5 \% \mathrm{CO}_{2}$ at $37^{\circ} \mathrm{C}$ for 1-2 weeks. The mixed brain cell cultures were shaken to remove less-adherent cells and treated with trypsin. The resulting astrocyte preparations were seeded at $2.5 \times 10^{4}$ cells $/ \mathrm{cm}^{2}$ on $12 \mathrm{~mm}$ coverslips, which were incubated overnight with $1 \mu \mathrm{g} / \mathrm{ml}$ poly-D-lysine (Sigma) for imaging analysis; or in wells of 96 well plates for luciferase assays. Astrocytes were subjected to experiments 1-3 weeks after seeding.

HEK293 cells (ATCC, Manassas, VA) were maintained in DMEM/F12 containing 10\% FBS and antibiotics, and subcultured by treating with $10 \mathrm{mM}$ EDTA/PBS. Cells were transfected with pN1-G-CaMP2 (RIKEN, Saitama, Japan) using Geneporter (Genlantis, San Diego, CA) and screened with $2 \mathrm{mg} / \mathrm{ml}$ G418 (Roche, Indianapolis, IN) and by fluorescence imaging to obtain stable transfectants expressing GCaMP2.

Calcium imaging. Astrocytes were washed three times with Basal Salt Saline (BSS; $129 \mathrm{mM} \mathrm{NaCl}, 4 \mathrm{mM}$ $\mathrm{KCl}, 1 \mathrm{mM} \mathrm{MgCl}_{2}, 2 \mathrm{mM} \mathrm{CaCl}_{2}, 10 \mathrm{mM}$-glucose, $10 \mathrm{mM}$ Hepes $\mathrm{pH}$ 7.4) and incubated with $7.5 \mu \mathrm{M}$ Fura2-AM (Dojin, Kumamoto Japan) at $30^{\circ} \mathrm{C}$ for one hour. After three additional washes with BSS, the cells were maintained in BSS containing $100 \mu \mathrm{M}$ sulfinpyrazone (Sigma), which inhibits Fura2 sequestration and secretion ${ }^{57}$, at room temperature until imaging experiments. HEK293 + GCaMP2 cell suspensions were added to Fura2-loaded 
astrocytes in BSS, and cocultured for more than two hours at room temperature. Fluorescence images were obtained using an inverted microscope, IX70 (Olympus, Tokyo, Japan) equipped with a filter exchanger (MAC5000; Ludl Electronic Products, Hawthorne, NY) and a cooled-CCD camera, Orca-R2 (Hamamatsu Photonics, Hamamatsu, Japan). The objective lens was UApo/340 20×/0.70w (Olympus). A 0.5x camera adaptor U-TV0.5XC (Olympus) was inserted before the camera. For Fura2-based calcium imaging, a set of F340 (Ex/ $\mathrm{DM} / \mathrm{Em}=340 / 500 / 535)$ and $\mathrm{F} 380(\mathrm{Ex} / \mathrm{DM} / \mathrm{Em}=380 / 500 / 535)$ images were obtained every three seconds. For simultaneous calcium imaging of Fura2-loaded astrocytes and HEK293 + GCaMP2 cells, a set of F380 and F480 $(\mathrm{Ex} / \mathrm{DM} / \mathrm{Em}=480 / 500 / 535)$ images were obtained every three seconds. Astrocytes were mechanically stimulated by touching them with 1-10 M $\Omega$ tips of a glass pipette (G150F-3, Warner Instruments, Hamden, CT), fabricated using P-87 (Sutter Instrument, Novato, CA). To maintain a constant stimulation force, contact by the tip was measured by input impedance using an amplifier (CEZ-2400; Nihon Kohden, Hyodo, Japan), and its approach was stopped immediately upon any increase in input impedance. The tip remained in contact during calcium wave propagation, because the waves were unaffected regardless of tip withdrawal.

Data analysis. Shading of fluorescence images was corrected by dividing the value of each pixel by the corresponding value in a control image. For Fura2-based calcium imaging, the $\Delta 340 / 380$ ration was calculated as $\frac{\mathrm{F} 340-\mathrm{BG} 1}{\mathrm{BG} 340-\mathrm{BG} 1} / \frac{\mathrm{F} 380-\mathrm{BG} 2}{\mathrm{BG} 380-\mathrm{BG} 2}$, where BG1 and BG2 were the fluorescence images obtained in the absence of excitation using filter sets for F340 and F380, respectively, and BG340 and BG380 (control image) were the F340 and F380 images of $10 \mu \mathrm{M}$ Fura2 potassium salt solution, respectively. For simultaneous imaging of GCaMP2 and Fura2, $\mathrm{F}^{\prime} 480=\frac{\mathrm{F} 480-\mathrm{BG}}{\mathrm{BG} 480-\mathrm{BG}}$, where BG was the fluorescence image obtained in the absence of excitation using a filter set for $\mathrm{F} 480, \mathrm{BG} 480$ was the $\mathrm{F} 480$ image of $10 \mu \mathrm{M}$ fluorescein, and $\mathrm{F}^{\prime} 380=\frac{\mathrm{F} 380-\mathrm{BG}}{\mathrm{BG} 380}$ was used to calculate $\Delta 480=\frac{F^{\prime} 480}{F_{0} 480}$ where Fo480 was the average of five $\mathrm{F}^{\prime} 480$ images before stimulation and $\Delta(1 / 380)=1 / \frac{F^{\prime} 380}{\text { Fo380 }}$, where $\mathrm{Fo} 380$ was the average of five $\mathrm{F}^{\prime} 380$ images before stimulation

Luciferase assay. Astrocytes were equilibrated with $\mathrm{BSS}$ at $30^{\circ} \mathrm{C}$ for longer than $15 \mathrm{~min}$, pretreated with inhibitors for $10 \mathrm{~min}$, and stimulated by incubation with $100 \mu \mathrm{l}$ BSS containing inhibitor and stimulus for $10 \mathrm{~min}$. A $50 \mu \mathrm{l}$ aliquot of the extracellular solution used for stimulation was mixed with $50 \mu \mathrm{l}$ assay reagent (ATP Bioluminocount Assay Kit CLS II, Sigma-Aldrich) and luciferase activity was measured using a luminometer (GLOMAX 20/20; Promega, Fitchburg, WI).

Materials. 18 $\beta$-Glycyrrhetinic acid, apyrase, ATP, thapsigargin, and U73122 were obtained from Sigma-Aldrich. DCPIB was obtained from Tocris (Bristol, UK); DIDS was from Tokyo Chemical Industry Co. Ltd (Tokyo, Japan); and GPN, vacuolin-1 and Xestospongin C were from Santa Cruz Biotechnology (Dallas, TX). Gap-19 was synthesized (HPLC grade) by MBL (Kyoto, Japan). All other chemicals were from Nacalai (Kyoto, Japan).

Statistical analysis. The values are expressed as mean values \pm SD. Differences among the values were analyzed using statistical methods mentioned in Figure Legends and differences with probability (p) values $<0.05$ were considered significant.

\section{References}

1. Charles, A. C., Merrill, J. E., Dirksen, E. R. \& Sanderson, M. J. Intercellular signaling in glial cells: calcium waves and oscillations in response to mechanical stimulation and glutamate. Neuron 6, 983-992 (1991).

2. Bowser, D. N. \& Khakh, B. S. Vesicular ATP is the predominant cause of intercellular calcium waves in astrocytes. The Journal of general physiology 129, 485-491, https://doi.org/10.1085/jgp.200709780 (2007).

3. Dani, J. W., Chernjavsky, A. \& Smith, S. J. Neuronal activity triggers calcium waves in hippocampal astrocyte networks. Neuron 8 , 429-440 (1992)

4. Simard, M., Arcuino, G., Takano, T., Liu, Q. S. \& Nedergaard, M. Signaling at the gliovascular interface. The Journal of neuroscience: the official journal of the Society for Neuroscience 23, 9254-9262 (2003).

5. Kuga, N., Sasaki, T., Takahara, Y., Matsuki, N. \& Ikegaya, Y. Large-scale calcium waves traveling through astrocytic networks in vivo. The Journal of neuroscience: the official journal of the Society for Neuroscience 31, 2607-2614, https://doi.org/10.1523/JNEUROSCI.5319-10.2011 (2011).

6. Hoogland, T. M. et al. Radially expanding transglial calcium waves in the intact cerebellum. Proc Natl Acad Sci USA 106, 3496-3501, https://doi.org/10.1073/pnas.0809269106 (2009).

7. Nedergaard, M. Direct signaling from astrocytes to neurons in cultures of mammalian brain cells. Science (New York, N.Y.) 263, 1768-1771 (1994).

8. Koizumi, S., Fujishita, K., Tsuda, M., Shigemoto-Mogami, Y. \& Inoue, K. Dynamic inhibition of excitatory synaptic transmission by astrocyte-derived ATP in hippocampal cultures. Proc Natl Acad Sci USA 100, 11023-11028, https://doi.org/10.1073/ pnas.1834448100 (2003).

9. Schipke, C. G., Boucsein, C., Ohlemeyer, C., Kirchhoff, F. \& Kettenmann, H. Astrocyte Ca2+ waves trigger responses in microglial cells in brain slices. FASEB journal: official publication of the Federation of American Societies for Experimental Biology 16, 255-257, https://doi.org/10.1096/fj.01-0514fje (2002).

10. Paemeleire, K. \& Leybaert, L. ATP-dependent astrocyte-endothelial calcium signaling following mechanical damage to a single astrocyte in astrocyte-endothelial co-cultures. Journal of neurotrauma 17, 345-358, https://doi.org/10.1089/neu.2000.17.345 (2000).

11. Pannasch, U. \& Rouach, N. Emerging role for astroglial networks in information processing: from synapse to behavior. Trends in neurosciences 36, 405-417, https://doi.org/10.1016/j.tins.2013.04.004 (2013).

12. Kuchibhotla, K. V., Lattarulo, C. R., Hyman, B. T. \& Bacskai, B. J. Synchronous hyperactivity and intercellular calcium waves in astrocytes in Alzheimer mice. Science (New York, N.Y.) 323, 1211-1215, https://doi.org/10.1126/science.1169096 (2009).

13. Torres, A. et al. Extracellular $\mathrm{Ca}(2)(+)$ acts as a mediator of communication from neurons to glia. Science signaling $\mathbf{5}$, ra8, https:// doi.org/10.1126/scisignal.2002160 (2012).

14. Hassinger, T. D., Guthrie, P. B., Atkinson, P. B., Bennett, M. V. \& Kater, S. B. An extracellular signaling component in propagation of astrocytic calcium waves. Proc Natl Acad Sci USA 93, 13268-13273 (1996). 
15. Theis, M. \& Giaume, C. Connexin-based intercellular communication and astrocyte heterogeneity. Brain research 1487, 88-98, https://doi.org/10.1016/j.brainres.2012.06.045 (2012).

16. Enkvist, M. O. \& McCarthy, K. D. Activation of protein kinase C blocks astroglial gap junction communication and inhibits the spread of calcium waves. Journal of neurochemistry 59, 519-526 (1992).

17. Hofer, T., Venance, L. \& Giaume, C. Control and plasticity of intercellular calcium waves in astrocytes: a modeling approach. The Journal of neuroscience: the official journal of the Society for Neuroscience 22, 4850-4859 (2002).

18. Butt, A. M. ATP: a ubiquitous gliotransmitter integrating neuron-glial networks. Seminars in cell \& developmental biology 22, 205-213, https://doi.org/10.1016/j.semcdb.2011.02.023 (2011).

19. Guthrie, P. B. et al. ATP released from astrocytes mediates glial calcium waves. The Journal of neuroscience: the official journal of the Society for Neuroscience 19, 520-528 (1999).

20. Macdonald, C. L., Yu, D., Buibas, M. \& Silva, G. A. Diffusion modeling of ATP signaling suggests a partially regenerative mechanism underlies astrocyte intercellular calcium waves. Frontiers in neuroengineering 1, 1, https://doi.org/10.3389/neuro.16.001.2008 (2008).

21. Scemes, E., Suadicani, S. O. \& Spray, D. C. Intercellular communication in spinal cord astrocytes: fine tuning between gap junctions and $\mathrm{P} 2$ nucleotide receptors in calcium wave propagation. The Journal of neuroscience: the official journal of the Society for Neuroscience 20, 1435-1445 (2000).

22. Scemes, E., Dermietzel, R. \& Spray, D. C. Calcium waves between astrocytes from Cx43 knockout mice. Glia 24, 65-73 (1998).

23. Wang, N. et al. Selective inhibition of $\mathrm{Cx} 43$ hemichannels by Gap 19 and its impact on myocardial ischemia/reperfusion injury. Basic research in cardiology 108, 309, https://doi.org/10.1007/s00395-012-0309-x (2013).

24. Morita, M. et al. Dual regulation of astrocyte gap junction hemichannels by growth factors and a pro-inflammatory cytokine via the mitogen-activated protein kinase cascade. Glia 55, 508-515, https://doi.org/10.1002/glia.20471 (2007).

25. Tallini, Y. N. et al. Imaging cellular signals in the heart in vivo: Cardiac expression of the high-signal Ca2+ indicator GCaMP2. Proc Natl Acad Sci USA 103, 4753-4758, https://doi.org/10.1073/pnas.0509378103 (2006).

26. Fischer, W. et al. Characterization of $\mathrm{P} 2 \mathrm{X} 3, \mathrm{P} 2 \mathrm{Y} 1$ and $\mathrm{P} 2 \mathrm{Y} 4$ receptors in cultured HEK293-hP2X 3 cells and their inhibition by ethanol and trichloroethanol. Journal of neurochemistry 85, 779-790 (2003).

27. Fumagalli, M. et al. Nucleotide-mediated calcium signaling in rat cortical astrocytes: Role of P2X and P2Y receptors. Glia 43, 218-203, https://doi.org/10.1002/glia.10248 (2003).

28. Liu, Y., Zhou, Y. \& Zhu, K. Inhibition of glioma cell lysosome exocytosis inhibits glioma invasion. PloS one 7, e45910, https://doi. org/10.1371/journal.pone.0045910 (2012).

29. Bowens, N. H., Dohare, P., Kuo, Y. H. \& Mongin, A. A. DCPIB, the proposed selective blocker of volume-regulated anion channels, inhibits several glutamate transport pathways in glial cells. Mol Pharmacol 83, 22-32, https://doi.org/10.1124/mol.112.080457 (2013).

30. Wang, Z., Tymianski, M., Jones, O. T. \& Nedergaard, M. Impact of cytoplasmic calcium buffering on the spatial and temporal characteristics of intercellular calcium signals in astrocytes. The Journal of neuroscience: the official journal of the Society for Neuroscience 17, 7359-7371 (1997).

31. Hansen, M., Boitano, S., Dirksen, E. R. \& Sanderson, M. J. A role for phospholipase C activity but not ryanodine receptors in the initiation and propagation of intercellular calcium waves. J Cell Sci 108(Pt 7), 2583-2590 (1995).

32. Young, S. H., Ennes, H. S. \& Mayer, E. A. Propagation of calcium waves between colonic smooth muscle cells in culture. Cell calcium 20, 257-271 (1996).

33. Choi, H. J., Sun, D. \& Jakobs, T. C. Astrocytes in the optic nerve head express putative mechanosensitive channels. Molecular vision 21, 749-766 (2015).

34. Vanoevelen, J. et al. Inositol trisphosphate producing agonists do not mobilize the thapsigargin-insensitive part of the endoplasmicreticulum and Golgi Ca2+ store. Cell calcium 35, 115-121 (2004).

35. Missiaen, L. et al. Ca2 + uptake and release properties of a thapsigargin-insensitive nonmitochondrial Ca2 + store in $\mathrm{A} 7 \mathrm{r} 5$ and 16HBE14o- cells. The Journal of biological chemistry 277, 6898-6902, https://doi.org/10.1074/jbc.M110939200 (2002).

36. Wang, Z., Haydon, P. G. \& Yeung, E. S. Direct observation of calcium-independent intercellular ATP signaling in astrocytes. Analytical chemistry 72, 2001-2007 (2000).

37. Lallouette, J., De Pitta, M., Ben-Jacob, E. \& Berry, H. Sparse short-distance connections enhance calcium wave propagation in a 3D model of astrocyte networks. Frontiers in computational neuroscience 8, 45, https://doi.org/10.3389/fncom.2014.00045 (2014).

38. Cotrina, M. L. et al. Connexins regulate calcium signaling by controlling ATP release. Proc Natl Acad Sci USA 95, 15735-15740 (1998).

39. Sasaki, T. et al. Application of an optogenetic byway for perturbing neuronal activity via glial photostimulation. Proc Natl Acad Sci USA 109, 20720-20725, https://doi.org/10.1073/pnas.1213458109 (2012)

40. Franke, H., Verkhratsky, A., Burnstock, G. \& Illes, P. Pathophysiology of astroglial purinergic signalling. Purinergic signalling 8 , 629-657, https://doi.org/10.1007/s11302-012-9300-0 (2012).

41. Zhang, Z. et al. Regulated ATP release from astrocytes through lysosome exocytosis. Nature cell biology 9, 945-953, https://doi. org/10.1038/ncb1620 (2007).

42. Pryazhnikov, E. \& Khiroug, L. Sub-micromolar increase in $[\mathrm{Ca}(2+)](\mathrm{i})$ triggers delayed exocytosis of ATP in cultured astrocytes. Glia 56, 38-49, https://doi.org/10.1002/glia.20590 (2008).

43. Qiu, Z. et al. SWELL1, a plasma membrane protein, is an essential component of volume-regulated anion channel. Cell 157, 447-458, https://doi.org/10.1016/j.cell.2014.03.024 (2014)

44. Voss, F. K. et al. Identification of LRRC8 heteromers as an essential component of the volume-regulated anion channel VRAC. Science (New York, N.Y.) 344, 634-638, https://doi.org/10.1126/science.1252826 (2014).

45. Hyzinski-Garcia, M. C., Rudkouskaya, A. \& Mongin, A. A. LRRC8A protein is indispensable for swelling-activated and ATPinduced release of excitatory amino acids in rat astrocytes. The Journal of physiology 592, 4855-4862, https://doi.org/10.1113/ jphysiol.2014.278887 (2014).

46. Liu, H. T., Akita, T., Shimizu, T., Sabirov, R. Z. \& Okada, Y. Bradykinin-induced astrocyte-neuron signalling: glutamate release is mediated by ROS-activated volume-sensitive outwardly rectifying anion channels. The Journal of physiology 587, 2197-2209, https:// doi.org/10.1113/jphysiol.2008.165084 (2009).

47. Sabirov, R. Z., Merzlyak, P. G., Islam, M. R., Okada, T. \& Okada, Y. The properties, functions, and pathophysiology of maxi-anion channels. Pflugers Archiv: European journal of physiology 468, 405-420, https://doi.org/10.1007/s00424-015-1774-5 (2016).

48. Sabirov, R. Z. \& Okada, Y. ATP release via anion channels. Purinergic signalling 1, 311-328, https://doi.org/10.1007/s11302-0051557-0 (2005).

49. Verderio, C. \& Matteoli, M. ATP mediates calcium signaling between astrocytes and microglial cells: modulation by IFN-gamma. Journal of immunology (Baltimore, Md.: 1950) 166, 6383-6391 (2001).

50. Bianco, F. et al. Astrocyte-derived ATP induces vesicle shedding and IL-1 beta release from microglia. Journal of immunology (Baltimore, Md.: 1950) 174, 7268-7277 (2005).

51. Davalos, D. et al. ATP mediates rapid microglial response to local brain injury in vivo. Nature neuroscience $8,752-758$, https://doi. org/10.1038/nn1472 (2005).

52. Kharlamov, A., Jones, S. C. \& Kim, D. K. Suramin reduces infarct volume in a model of focal brain ischemia in rats. Experimental brain research 147, 353-359, https://doi.org/10.1007/s00221-002-1251-1 (2002). 
53. Burnstock, G. An introduction to the roles of purinergic signalling in neurodegeneration, neuroprotection and neuroregeneration. Neuropharmacology, https://doi.org/10.1016/j.neuropharm.2015.05.031 (2015).

54. Talhouk, R. S., Zeinieh, M. P., Mikati, M. A. \& El-Sabban, M. E. Gap junctional intercellular communication in hypoxia-ischemiainduced neuronal injury. Progress in neurobiology 84, 57-76, https://doi.org/10.1016/j.pneurobio.2007.10.001 (2008).

55. Alibrahim, A. et al. Neuroprotective effects of volume-regulated anion channel blocker DCPIB on neonatal hypoxic-ischemic injury. Acta pharmacologica Sinica 34, 113-118, https://doi.org/10.1038/aps.2012.148 (2013).

56. Han, Q. et al. DCPIB, a potent volume-regulated anion channel antagonist, attenuates microglia-mediated inflammatory response and neuronal injury following focal cerebral ischemia. Brain research 1542, 176-185, https://doi.org/10.1016/j.brainres.2013.10.026 (2014).

57. Di Virgilio, F., Steinberg, T. H. \& Silverstein, S. C. Inhibition of Fura-2 sequestration and secretion with organic anion transport blockers. Cell calcium 11, 57-62 (1990).

\section{Acknowledgements}

This work was supported by a Grant-in-Aid for Scientific Research on the Innovative area 'Cellular and Molecular Basis for Neurovascular Wiring’ (\#23122513, Japan), a Grant-in-Aid for Scientific Research (B) (\#23300133, Japan), the Smoking Research Foundation (Japan) and the Takeda Science Foundation (Japan). We thank Dr. Junichi Nakai for providing pN1-G-CaMP2. We thank Dr. Mamiko Ozaki (Kobe Univ) for scientific discussion.

\section{Author Contributions}

Y.F., S.M. and M.M. designed the study and carried out data acquisition and analysis. Y.F. and M.M. wrote the paper. All authors reviewed the manuscript. M.M. and S.M. wrote the manuscript and Y.F. prepared the figures. All authors reviewed the manuscript.

\section{Additional Information}

Competing Interests: The authors declare that they have no competing interests.

Publisher's note: Springer Nature remains neutral with regard to jurisdictional claims in published maps and institutional affiliations.

(c) (i) Open Access This article is licensed under a Creative Commons Attribution 4.0 International

License, which permits use, sharing, adaptation, distribution and reproduction in any medium or format, as long as you give appropriate credit to the original author(s) and the source, provide a link to the Creative Commons license, and indicate if changes were made. The images or other third party material in this article are included in the article's Creative Commons license, unless indicated otherwise in a credit line to the material. If material is not included in the article's Creative Commons license and your intended use is not permitted by statutory regulation or exceeds the permitted use, you will need to obtain permission directly from the copyright holder. To view a copy of this license, visit http://creativecommons.org/licenses/by/4.0/.

(C) The Author(s) 2017 